\title{
Ebû'l-Berakât el-Bağdâdî Üzerine Çalışmalar: Bir Kaynakça Denemesi
}

\author{
Yrd. Doç. Dr. Tuna TUNAGÖZ*
}

Atıf / @)- Tunagöz, T. (2017). Ebû'l-Berakât el-Bağdâdî Üzerine Çalışmalar: Bir Kaynakça Denemesi, Çukurova Üniversitesi Ilahiyat Fakültesi Dergisi, 17 (1), 187-225.

Öz- Bu makalede, İslâm felsefesi tarihinin önemli temsilcilerinden birisi olan Ebû'l-Berakât el-Bağdâdî (ö. 547/1152) üzerine yapılan akademik çalışmalar hakkında bir kaynakça oluşturulmuştur. Çalışmada, öncelikle Bağdâdî'nin ilmî kişiliği hakkında bilgi verilmiş, ardından kaynakçanın yöntemi açıklanmıştır. Bunları takiben, Bağdâdî'nin kendi eserlerinin yazmaları, neşirleri ve çevirileri; filozofun hayatı ve eserleri hakkında bilgi veren klasik ve muasır kaynaklar; onun hakkında yayımlanmış kitap, kitap bölümü, makale ve ansiklopedi maddesi, bildiri düzeyinde eserler listelenmiştir. Çalışma, değerlendirme ve sonuç bölümü ile tamamlanmıştır. Bağdâdî hakkında yapılan çalışmaların son zamanlarda hız kazandığı ve onun fizik, metafizik teorileri ile felsefesindeki eleştirelliğe odaklanmış olduğu çalışmanın temel bulguları arasındadır. Bununla birlikte, filozofun bazı eserlerinin henüz neşredilmediği ve onun düşünce dünyasındaki meselelerin önemli bir kısmının henüz incelenmediği görülmektedir. Yine, Bağdâdî'nin fikrî kaynakları ve etkileri araştırmacıların ilgisini beklemektedir.

Anahtar sözcükler- Ebû'l-Berakât el-Bağdâdî, kaynakça, İslâm Felsefesi Tarihi, İslâm Bilim Tarihi, İslâm Tıp Tarihi

\section{$\S \S \S$}

Makalenin geliş tarihi: 22.05.2017; Yayına kabul tarihi: 19.06.2017

* Çukurova Üniversitesi İlahiyat Fakültesi İslam Felsefesi Anabilim Dalı, e-posta: ttunagoz@cu.edu.tr. Bu çalışma, Çukurova Üniversitesi BAP Koordinasyon Birimi tarafından desteklenen 8485 numaralı Bireysel Araştırma Projesi kapsamında hazırlanmıştır. 


\section{Giriş}

Ebû'l-Berakât Hibetullâh b. 'Alî b. Melkâ el-Bağdâdî (ö. 547/1152), metafizik, mantık, fizik, psikoloji, tıp, gökbilim ve eczacılık sahalarında eserler vermiş bir filozoftur. Bağdâdî ile aynı dönemde yaşayan ilahiyat âlimi ve tarihçi Zahîru'd-Dîn el-Beyhakî (ö. 565/1169), bazılarının onu Aristoteles'e (ö. m.ö. 384) denk bir filozof olarak değerlendirdiğini aktarır. ${ }^{1} \mathrm{Bu}$ değerlendirmenin mübalağalı olduğu söylenebilir; fakat Bağdâdî'nin yaygın biçimde "Evḥadu'zZamân" (Çağın Eşsizi) lakabıyla anılmış olması² döneminde kazandığı ilmî saygınlığın açık bir ifadesidir.

Filozof, şöhretini öncelikli olarak tıptaki uzmanlığına borçludur. Klasik dönem kültür tarihçisi Ḳıfțî (ö. 646/1248), çağdaşı tabiplerin çeşitli meseleleri ona sorduğu ve onun verdiği cevaplardan oluşan notların elden ele dolaştığı bilgisini vermektedir. ${ }^{3}$ Kayıp durumdaki Ihtișâru't-Teşrîh (Anatomi Özeti) ve elAkrâbâżîn (İlaç Formülleri Kitapçığı) ile günümüze ulaşan Berşe aşâ (Hızla İyileştiren Formül) ve Emînu'l-Ervâh (Ruhların Dayanağı) onun tıp sahasındaki eserleridir.

Yetkin bir tabip olmakla birlikte, Bağdâdî adını daha çok Meşşâî felsefeye yönelttiği eleştiriler ve özgün bir felsefî sistem kurma teşebbüsüyle duyurmuştur. Ķıfți onun mantık, fizik ve ilahiyat bahislerinden oluşan başeseri elKitâbu'l-Mu 'teber fî'l-Hikme'yi (Felsefî Değerlendirmeler Kitabı), "bu devirde bu sahada yazılmış en güzel eser"4 olarak nitelemektedir. Yine onun Risâle fîl- 'Aḳl ve Mâhiyyetih (Akıl ve Mahiyeti Hakkında Risale) isimli eseri, Meşşâîlere alternatif bir akıl anlayışı teklif etmektedir. Sadece bazı parçalarına sahip olduğumuz Kitâbu'n-Nefs (Nefs Kitabı) ise özgün nefs kuramının ilk adımlarını temsil etmektedir.

Filozofun ayrıca Risâle fî Mâhiyyeti'l-Melâl (Usancın Mahiyeti Hakkında Risale) isimli psikoloji sahasında ve Risâle fî Sebebi Zuhûri'l-Kevâkib Leylen ve Hafâ'ihâ Nehâran (Yıldızların Yalnızca Geceleri Görülüp Gündüzleri Görülmemesi Hakkında Risale) isimli gökbilim sahasında bir eseri mevcuttur.

Bağımsız filozof Ebû'l-Berakât el-Bağdâdî'nin İslâm düşünce tarihinin başat temsilcilerinden birisi olduğu söylenemez. Fakat özellikle yaşadığı dö-

1 Beyhaḳ̂, Tetimmetu Șıâni'I-Hikme, s. 152. Dipnotlardaki eserlerin künyeleri çalışma içindeki listelerde yer almaktadır.

2 İbn Ebî Ușaybi'a, 'Uyûnu'l-Enbâ', s. 349.

3 Kııftîi, inhbâru'l-'Ulemâ', s. 226.

4 Kuıtṭî, Ihbâru'l- 'Ulemâ', s. 224. 
nemde egemen felsefî sistem olan Yeni Eflatuncu Aristoculuğa yönelttiği tenkitler bağlamında kendisinden sonraki pek çok düşünüre etki etmiştir:

Felsefî kelâmın en büyük temsilcilerinden birisi olan Fahru'd-Dîn erRâzî (ö. 606/1210), Bağdâdî’den, kelâmî değerler dizisine yaklaştığı tabiat, nefs ve ilahiyat bahislerinde oldukça faydalanmıştır. İşrâkî filozof Şehrazûrî (ö. $687 / 1288$ sonrası), onun filozoflara yönelttiği eleştirilerin çoğunluğunu Bağdâdî kanalından elde ettiğini ifade etmektedir. ${ }^{5}$

Çok yönlü âlim ve felsefe eleştirmeni İbn Teymiyye (ö. 728/1328), Bağdâdî'yi Meşşâî düşünceyi taklit etmeyen ve nübüvvet ışığıyla aydınlanan bir düşünür olarak takdim etmiştir. İbn Teymiyye, Bağdâdî'nin, ilâhî sıfatlar, zat-sıfat ilişkisi, Allah'ın tikelleri bilmesi gibi meselelerdeki yorumlarını saygı ve takdirle anmış ve yer yer onun düşüncelerinden istifade etmiştir. ${ }^{6}$

Bu düşünürlerin dışında İşrâkî felsefenin kurucusu Suhraverdî (ö. 587/1191), onun takipçisi ve şârihi Şehrazûrî (ö. 687/1288 sonrası), Ekberî mutasavvıf ve filozof Dâvûd el-Ḳayșerî (ö. 751/1350), muhakkik felsefî kelâmcılar 'Aḍudu'd-Dîn el-Î́cî (ö. 756/1355), Seyyid Şerîf el-Curcânî (ö. 816/1413) ve Celâlu'd-Dîn ed-Devvânî (ö. 908/1502) Bağdâdî'nin düşüncelerinden yararlanmışlardır. ${ }^{7}$

Bağdâdî'nin fikirleri, ayrıca Ortaçağ Yahudi filozofları Abraham bar Hiyya (ö. ykl. 1136), İbn Kemmûne (ö. 683/1284) ${ }^{8}$, Gersonides (ö. 1344) ve Hasday Kreskas (ö. ykl. 1411) ile Ortaçağ Hristiyan filozofları Johannes Buridanus (ö. 1358'ten sonra) ve Saksonyalı Albertus'ta (ö. 1390) yankı bulmuştur. ${ }^{9}$

Bu makale, yukarıda ilmî kişiliği tasvir edilen Ebû'l-Berakât elBağdâdî'nin eserleri ve onun düşünce sistemi üzerine yapılan çalışmalara dair bir kaynakça niteliğindedir. Çalışmanın hedefi, Bağdâdî üzerine inceleme yapacak bir araştırmacıya hangi yayınlarla ilgilenmesi ve hangi araştırma konularına yönelmesi gerektiği hususunda rehberlik yapmaktır. Çalışma, Bağdâdî ile ilgili yapılmış tüm eserleri eksiksiz biçimde tespit ettiği iddiasında de-

5 Şehrazûrî, Bilgelerin Tarihi ve Özdeyişleri, s. 915.

6 Çağrıcı, "Ebü'l-Berekât el-Bağdâdî”, s. 307-308.

7 Çağrıcı, "Ebü'l-Berekât el-Bağdâdî”, s. 307.

8 Langermann, "Al-Baghdadi, Abu 'I-Barakat (fl. c.1200-50)", s. 637-638.

9 [Roth], "Hibat Allah", s. 462; Pines, "Studies in Abu'l-Barakāt Al-Baghdādī's Poetics and Metaphysics", s. 169-170. Bağdâdî'nin hayatı, eserleri ve etkisi hakkında ayrıntılı bilgi için bkz. Tunagöz, Ebü'l-Berekât el-Bağdâdî Felsefesinde Tanrı, s. 2455. 
ğildir. Lakin bu hedefe yaklaşabilmek için elden geldiğince gayret göstermiş durumdadır.

Çalışmada öncelikle Bağdâdî’nin eserlerinin yazmaları listelenmiştir. Yazmaları bulunan eserler alt başlıklara ayrılmış ve mevcut yazmaların her birisi elden geldiğince ayrıntılı biçimde tasvir edilmiştir. Bu kısmı Bağdâdî'nin eserlerinin neşir ve çevirilerine ayrılan bölüm takip etmiştir. Neşirler ve çeviriler ayrı başlıklar halinde ele alınmıştır. Bu bapta yapılan çalışmaların bir kısmı tez ve makaleler içerisinde yer almaktadır. Bahsedilen türdeki eserlere dair açıklamalar yapılmış ve onlar tekrardan kaçınma düşüncesiyle tez ve makale bölümleri içerisinde yeniden zikredilmemiştir. Aynı gerekçeyle, herhangi bir çalışma sadece ilk kez ele alındığı yerde anılmış; bir eserin yeni baskısı ve tıpkıbasımı tespit edilmişse buna yönelik bilgiler dipnotta ifade edilmiş, ayrı başlık açılmamıştır. Fakat başka bir yayın türüyle tekrarlanan çalışmalar, makale sonundaki değerlendirme ve sonuç kısmında dikkate alınmıştır.

Bağdâdî'nin hayatı ve eserleri ile ilgili açıklama yapan kaynaklar klasik ve muasır alt başlıklarına ayrılmıştır. Bu eserlerin Bağdâdî’ye yönelik bölümlerinin başlıkları tırnak içinde belirtilmiştir. Kitap bölümleri başlığı altındaki çalışmaların büyük kısmı doğrudan Bağdâdî için ayrılmış bölümlerdir. Herhangi bir yayın türünde Bağdâdî'nin isminin geçmediği girdiler okuyucuyu yanıttmamalıdır. Zira bunların tümü Bağdâdî'nin düşüncelerine yönelik incelemeler içerdiği için listeye dâhil edilmiştir. Bilimsel toplantılarda sunulan çaışmalar bölümünde basılı olanlar ve olmayanlar bir arada zikredilmiştir. Hazırlık veya baskı aşamasında olan eserlere dipnotlarda dikkat çekilmiştir.

Yazarların isimleri alfabetik olarak sıralanmış ve sıralamada "el/al" takıları dikkate alınmamıştır. Bir kaynakça çalışmasının hitap edeceği kitlenin genel olabileceği düşüncesiyle, Arapça ve Farsça sözcüklerin imlasında Türkiye'de yaygın olan usule değil, o sözcüklerin ait olduğu dildeki asına sadık kalınmıştır. Kullanılan kaynaklardaki Arapça ve Farsça harflerin çevriyazımları şu şekildedir:

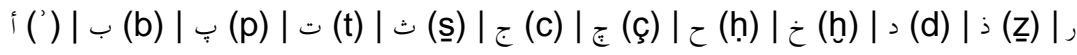

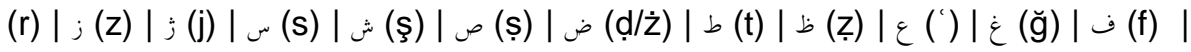

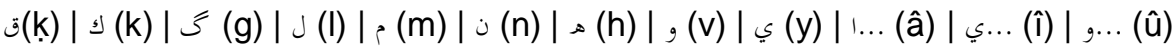

Çalışmada aşağıda listelenen kısaltmalar kullanılmıştır:

b.: bin/ibn | b.b.: basımevi belirtilmemiş | c.: cilt/volume/mucelled | çev.: çeviren/translator/el-mutercim | Dânişgâh: Kitâbhâne-i Merkezî-i Dânişgâh-i Tahran | Dânişgede: Kitâbhâne-i Dânişgede-i İlâhiyyât-i Dânişgâh-i Tahrân | ist.: istinsah | Mar'aşî: Kitâbhâne-i Bozorg-i Hażret-i Âyetullâhi'l- 
'Uzmâ Mar'aşî-i Necefî | Melik: Mu'essese-i Kitâbhâne ve Mûze-i Millî-i Melik | muk.: mukabele | m.ö.: milattan önce | müst.: müstensih | nr.: numara | nşr.: neşreden | Rażavî: Kitâbhâne, Sâzmân-ı Kitâbhânehâ, Mûzehâ ve Merkez-i Esnâd-i Âstân-i Ḳuds-i Rażavî | ö.: ölümü | s.: sayfa/page/ șafḥa | Sipehsâlâr: Kitâbhâne-i Medrese-i 'Âlî-i Şehîd Muțahharî-i Sipehsâlâr | Şûrâ-yı İslâmî: Kitabhâne, Mûze ve Merkez-i Esnâd-i Meclis-i Şûrâ-yı İslâmî | Şûrâ-yı Millî: Mûze ve Merkez-i Esnâd-i Meclis-i Şûrâ-yı Millî | t.y.: tarih yok/no date/dûne târîh | y.: yaprak/folio/varak | YEK: Yazma Eser Kütüphanesi | v.dğr.: ve diğerleri/and others/ve'l-âhârûn | ykl.: yaklaşık | yy.: yüzyıl.

\section{Eserlerinin Yazmaları}

\section{1. el-Kitâbu'I-Mu 'teber fí'I-Hikme}

el-Bağdâdî, Ebû'l-Berakât, el-Kitâbu'l-Mu'teber fî'l-Hikme, İstanbul, Süleymaniye YEK, Fâtih, nr. 3224, 194 y., müst. Hibetullâh b. Muhammed b. 'Alî b. el-Hasen el-Ḳuraşî, Zû́'l-ḳa de 595/Ağustos 1199. ${ }^{10}$

—, el-Kitâbu'l-Mu'teber fî'l-Hikme, İstanbul, Köprülü YEK, Fâzıl Ahmed Paşa, nr. 919, 252 y. ${ }^{11}$

Fâtih, nr. 3225, 209 y..$^{12}$

—, el-Kitâbu'l-Mu'teber fî'l-Hikme, İstanbul, Süleymaniye YEK, Fâtih, nr. 3226, 212 y. ${ }^{13}$

—, el-Kitâbu'l-Mu'teber fîl'-Hikme, İstanbul, Süleymaniye YEK, Es'ad Efendi, nr. 1931, 332 y., müst. Muhammed b. ez-Zahîr b. Mes ûd b. Evḥad b. Mes'ûd b. Aḥmed el-Ḳârî (el-'Alâ' el-Ebîverdî), ist. Gürgenç

10 Nüsha, Bağdâdî'nin el-Kitâbu'l-Mu'teber'i öğrencisine imlâ ettirdiği nüshadan istinsah edilen nüshadan istinsah edilmiştir. Eser bu yolla telif edildiğinden, bu nüshanın soyağacının asıl nüshaya dayandığı söylenebilir. Müstensih kitabı dört cilt olarak istinsah etmiştir; fakat elimizdeki nüsha yalnızca ilahiyat bölümünü intiva eden dördüncü cilttir. Mantık ve fizik bölümlerine karşılık gelen ilk üç cilt kayıp durumdadır.

11 Müstensih kitabı dört cilt olarak istinsah etmiştir; fakat elimizdeki nüsha kitabın yalnızca mantık bölümünü intiva eden birinci cilttir. Nüshanın üçüncü cildi Fâtih 3225 'te, dördüncü cildi Fâtih 3226'da kayıtlıdır.

12 Bir önceki nüsha ile aynı kalemden çıkan nüsha, kitabın fizik bölümünün son iki cüz'ünü (nebat, hayevan ve nefs) ihtiva eden üçüncü cilttir. Kayıp olan ikinci ciltte fizik bölümünün ilk dört cüz'ünün yer aldığı anlaşılmaktadır.

13 Önceki iki nüsha ile aynı kalemden çıkan nüsha, kitabın ilahiyat bölümünü intiva eden dördüncü cilttir. 
(Curcâniyye), 12 Zû́l-ka de 742/19 Nisan 1342; muk. Kırım, Azak, 25 Cumâdâ'l-ûlâ 744/15 Ekim 1343. ${ }^{14}$

, el-Kitâbu'l-Mu'teber fî'l-Hikme, İstanbul, Süleymaniye YEK, Lâleli, nr. 2553, Ramażân 564/Ağustos 1169. ${ }^{15}$

, el-Kitâbu'l-Mu 'teber fî'l-Hikme, İstanbul, Topkapı Müzesi YEK,

III. Ahmed, nr. 3222, 225 y. ${ }^{16}$

——, el-Kitâbu'l-Mu 'teber fî̀l-Hikme, Şam, el-Mektebetu'z-Zâhiriyye, nr. 6789, 250 y. ${ }^{17}$

—, el-Kitâbu'l-Mu'teber fî'l-Hikme, Necef, Mektebetu'r-Ravḍati'lHaydariyye, nr. 576, müst. Ebû Sa'd b. Nefîs b. Mubârak, Bağdat, Şevvâl 538/Nisan $1144 .^{18}$

, el-Kitâbu'I-Mu'teber fî'I-Hikme, Meşhed, Rażavî, nr. 5666, 444

y. ${ }^{19}$

y. $255 b-331 a .^{20}$

el-Kitâbu'I-Mu 'teber fî'l-Hikme, Tahran, Dânişgâh, nr. 1993/2,

—_, el-Kitâbu'l-Mu 'teber fí'l-Hikme, Tahran, Melik, nr. 5678, 76 y.,

12./18. yy. ${ }^{21}$

, el-Kitâbu'l-Mu'teber fîl-Hikme, Tahran, Sipehsâlâr, nr. 8375, 197 y., müst. Edîb Pişvârî, 14./20. yy.22

14 Müstensih, kitabın üç bölümünü tek cilt içerisinde istinsah etmiştir. Kitabın tüm bölümlerini içeren nüsha, bu yönüyle diğerlerinden ayrılmaktadır.

15 Müstensih kitabı dört cilt olarak istinsah etmiştir; fakat elimizdeki nüsha kitabın mantık ve ilahiyat bölümlerini intiva eden birinci ve dördüncü cilttir.

16 Müstensih kitabı dört cilt olarak istinsah etmiştir; fakat elimizdeki nüsha kitabın fizik bölümünün ilk kısımlarını ihtiva eden ikinci cilttir.

17 Nüshada kitabın fizik ve ilahiyat bölümleri yer almaktadır.

18 Bu nüsha eldekiler içerisinde en eski olanıdır. Bağdâdî hayatta iken, kendisi gibi Yahudi iken ihtida eden öğrencisi İshâk b. İbrâhîm b. 'Azrâ için istinsah edilmiştir.

19 Nüsha kitabın ilk bölümü olan mantığın üçüncü makalesi kıyas ile başlayıp ilahiyatın son faslıyla bitmektedir. İlahiyatın sonundaki "ta 'lîḳ" kısmı mevcut değildir.

20 Nüshada fizik bölümünün hareket ve zaman konularına ait beş faslı yer almaktadır.

21 Nüshada "Sem 'u'l-Kiyân" ve "es-Semâ' ve'l- Âlem" bahisleri yer almaktadır.

22 Nüshada nefs bahsinin ikinci faslından başlayıp on birinci faslına kadar devam etmektedir. 
—_, el-Kitâbu'l-Mu'teber fî'l-Hikme, Tahran, Şûrâ-yı İslâmî, nr. 10612, müst. Muḥammed b. Ebî'l-Fevâris b. Ebî Sa 'd, 13 Rabî'u'l-âhir 599/30 Aralık $1202 .^{23}$

—-, el-Kitâbu'l-Mu'teber fî'l-Hikme, Kazvin, Kitâbhâne-i Hanedân-i Mîr Huseynâ-yı Kazvînî, nr. 174.24

-, el-Kitâbu'l-Mu'teber fî'l-Hikme, Kum, Kitâbhâne-i Merkez-i Ị̇yâ-i Mîrâș-ı İslâmî, nr. 3457, 135 y., 11./17. yy. ${ }^{25}$

Hâzihî'l-Kerârîs min Kitâbi'l-Mu'teber min Tabî'iyyâtı Evhadi'zZamân, Konya Bölge YEK, Yusuf Ağa, nr. 4690/6, y. 1a-72a, 6./12. yy. ${ }^{26}$

\section{Kitâbu'n-Nefs}

el-Bağdâdî, Ebû'l-Berakât, Min Kitâb li-Ebî'l-Berakât el-Bağdâdî fî 'IIlmi'n-Nefs, İstanbul, Süleymaniye YEK, Ayasofya, nr. 4855, y. 104a-109b, 713-721/1313-1321.

“Kâle fî Kitâbi'n-Nefs ellezî Șannefehû Kadîmen fî Fașlin minh: (...)", el-Kitâbu'l-Mu'teber fî'l-Hikme: en-Nefs sonunda, Meşhed, Rażavî, nr. 5666, y. 327b-328a. ${ }^{27}$

23 Nüsha kitabın ilk bölümü olan mantığın üçüncü makalesi "kıyas" ile başlayıp fizik kitabının "nefs" bahsine kadar devam etmektedir (Merâğî, Fihrist-i Nushahâ-i Hatțî-i Kitâbhâne-i Meclis-i Şûrâ-yı İslâmî, c. 33/1, s. 131). Kitâbḩâne-i Huseyn Miftâh, nr. 1321 kaydı altında, aynı özelliklere sahip bir nüshadan bahsedilmektedir (Dirâyetî, Fihristvâre-i Destneveşthâ-i Îrân, c. 9, s. 838). Bahsedilen nüshanın bu şahsî kütüphaneden Meclis-i Şûrâ-yı İslâmî̀ye aktarıldığını, her iki kaydın aynı metinden bahsettiğini sanıyorum.

24 Nüsha, fizik bölümünün başından nefs bahsine kadardır.

25 Nüsha, fizik bölümünün bir kısmını ihtiva etmektedir.

26 Nüsha, kitabın fizik bölümünün son kısmı olan nefs bahsinin ikinci ve on dokuzuncu fasılları ile ilahiyatın birkaç faslını intiva etmektedir. el-Kitâbu'l$M u$ 'teber'in tespit edebildiğim yazmaları yukarıdakilerle sınırıdır. Bununla birlikte, eserin ilk neşrini gerçekleştiren muhakkiklerden Zeynu'l-Ấbidîn el-Mûsevî, Şerafettin Yaltkaya'nın yardımıyla İstanbul'dan, müellif nüshasıyla mukabele edilmiş, yazısı iyi, kadim ve sıhhatli bir nüsha satın aldıklarını ve bu nüshanın Haydarabad'daki Âsafiyye Kütüphanesi'ne nakledildiğini ifade etmektedir (c. 1, s. 278-279; c. 3, s. 253). Tahkikte "صف" harfleriyle simgelenen bu nüshanın kaynağının Yahyâ b. Vefâ' tarafından müellif metninden çoğaltılan nüsha olduğu ve istinsahın el-Muzaaffer b. 'Umer b. Muhammed b. 'Alî el-Meyyâfârikî tarafından Raceb 556/Haziran-Temmuz 1161 tarihinde tamamlandığı tahkik içindeki bilgilerden anlaşılmaktadır (c. 1, s. 282; c. 2, s. 451). Eğer kaybomamışsa nüshanın hâlâ Âsafiyye Kütüphanesi'nde olması gerekir. Fakat tüm araştırmalarıma rağmen elimizdeki en eski tarihli bu tam nüshanın izine rastlayamadım. 


\section{Risâle fî'l- Akl ve Mâhiyyetih}

el-Bağdâdî, Ebû'l-Berakât, Risâle fî'l- 'Aḳl ve Mâhiyyetih, Leipzig, Universitätsbibliothek, Vollers, nr. 882/1, y. 1a-17a.

\section{Risâle fî Sebebi Zuhûri'l-Kevâkib Leylen ve Hafâ'ihâ Nehâran}

el-Bağdâdî, Ebû'l-Berakât, Risâle fî Sebebi Zuhûri'l-Kevâkib Leylen ve Hafâ'ihâ Nehâran, Tahran, Şûrâ-yı Millî, nr. 3923/22, s. 200-203, 8./14. yy.

—-, Risâle fî Zuhûri'l-Kevâkib Leylen ve Hafâ'ihâ Nehâran, Berlin, Staatsbibliothek, Petermann II, nr. 466/8, y. 47a-48b, müst. Muḥammed b. Ahmmed es-Sâvî, ykl. 890/1485.

—_, Risâle fî Sebebi Ẓuhûri'l-Kevâkib Leylen ve Hafâ'ihâ Nehâran, Tahran, Dânişgâh, nr. 2783/1, s. 1-5, 14./20. yy.

, Risâle fî Sebebi Zuhûri'l-Kevâkib Leylen ve Hafâ'ihâ Nehâran, Meşhed, Rażavî, nr. 6012, Mordâd 1311/Ağustos 1932.

Risâle fî Zuhûri'l-Kevâkib Leylen ve Hafâ'ihâ Nehâran, Tahran, Dânişgâh, nr. 6710/19, y. 65a-65b, müst. Nașîru'd-Dîn Muhammed erRażavî.

[el-Bağdâdî, Ebû'l-Berakât], Zuhûru'l-Kevâkib Leylen ve İhtifâ'ihâ Nehâran, Tahran, Melik, nr. 2412/2, s. 25-31, müst. Muḥammed b. 'Alî edDâmiğânî, 659/1260-61.28

, Risâle fî Sebebi Z̦uhûri'l-Kevâkib Leylen ve Hafâ'ihâ Nehâran, Meşhed, Kitâbhâne, Rażavî, nr. 11452/16, 3 y., müst. Şihâbu'd-Dîn 'Alî ețTabațabâ'î, 27 Žû'l-ḳa de 1019/10 Şubat 1611.

, Risâle fî Sebebi Zuhûri'l-Kevâkib Leylen ve Hafâ'ihâ Nehâran, Tahran, Dânişgâh, nr. 4732/2, s. 27-31, 12./18. yy.

—, [Risâle fî Sebebi Zuhûri'l-Kevâkib Leylen ve Hafâ'ihâ Nehâran], Krakow, Jagiellońska Biblioteka, Ms. or. fol. 218/34, y. 440b-443a, $1061 / 1651$.

27 Her iki yazma Bağdâdî'nin Kitâbu'n-Nefs isimli eserden pasajlar içermektedir. Bağdâdî'nin bu eseri değerlendirme, neşir ve İngilizce tercüme olarak yayıma hazırlanmaktadır: Wan Abdullah, Wan Suhaimi, An Analysis, Annotated English Translation and Critical Edition of Abū al-Barakāt el-Baghdādî's Treatise on Soul: Kitāb fî 'Ilm al-Nafs,

http://www.kalamresearch.com/ kalamres/article.php?artID=48 (Erişim:

01.04.2017).

28 Bu nüsha ve takip eden üç nüshada müellif ismi yer almamaktadır. 
İbn Sînâ, Ebû 'Alî, Risâle fî Ru'yeti'l-Kevâkib bi'l-Leyl lâ bi'n-Nehâr, İstanbul, Süleymaniye YEK, Ayasofya, nr. 4832/13, y. 57a-57b, 700/130001.29

—-, Risâle fî Ru'yeti'l-Kevâkib bi'l-Leyl lâ bi'n-Nehâr, Meşhed, Rażavî, nr. 5295/1, s. 1-2, müst. Muhammed Ḥuseyn b. Halef et-Tebrîzî, 1041/1631-32.

—, Risâle fî Ru'yeti'l-Kevâkib bi'l-Leyl ve'n-Nehâr, Meşhed, Rażavî, nr. 5590/3, s. 146-149, 12./18. yy.

—, Risâle fî Ru'yeti'l-Kevâkib bi'l-Leyl lâ bi'n-Nehâr, Meşhed, Rażavî, nr. 12124/10, 1 y., müst. Esedullâh b. Muneccim el-Mâzenderânî, $1308 / 1890-91$.

—-, Risâle fî Ru'yeti'l-Kevâkib fî'l-Leyl lâ bi'n-Nehâr, Tahran, Kitâbhâne-i Asgar Mehdevî, nr. 282/6, s. 84, müst. Muhammed Tâhir elMeşhedî, 1309/1891-92.

—-, Risâle fî Ru'yetil-Kevâkib fî'l-Leyl lâ fi'n-Nehâr, Meşhed, Rażavî, nr. 12297/27, s. 363-364, müst. Muhammed Ṭâhir el-Meşhedî, 1309/1891-92.

—_, Risâle fî Ru'yeti'l-Kevâkib fî'l-Leyl, Tahran, Dânişgede, nr. 709/2, y. 27b-28b, müst. Habîb es-Simnânî, 29 Mordâd 1312/20 Ağustos 1933.

\section{Risâle fî Mâhiyyeti'l-Melâl}

el-Bağdâdî, Ebû'l-Berakât, Risâle li-Ebî'l-Berakât el-Bağdâdî fî Mâhiyyeti'l-Melâl, Tahran, Melik, nr. 6188/20, s.136-143, 11./17. yy.

—-, Hâzihî Risâletun fî̀l-Melâl li-Ebî̀l-Berakât el-Bağdâdî, Kum, Mar'aşî, nr. 12388/6, y. 201a-203b, 9./15. yy.

29 Bu nüsha ve takip eden altı nüsha, daha önceki nüshalarla aynı metne sahip olmakla birlikte, risaleyi farklı isimle İbn Sînâ'ya atfetmiştir. Nüshalar gerçekte Bağdâdî külliyatına dâhildir. Bahsedilen karışıklığın nedeni, eserin Bağdâdî’ye aidiyetine yönelik kanıtlar ve tüm nüshalar hakkında bilgi için bkz. Tunagöz, "İslam Bilim Tarihinden Bir Sayfa: Risâle fî sebebi zuhûri'l-kevâkib leylen ve hafâiha nehâran", s. 41-49, 51-54. Bu nüshanın yer aldığı mecmua tıpkıbasım olarak yayımlanmıştır: İbn Sînâ, "Risâle fî Ru'yetil-Kevâkib bi'l-Leyl lâ bi'n-Nehâr", Mecmû'u Ayâșûfyâ 4832: Makâlât fî'r-Riyâdiyyât ve'l-Felsefe ve'l-Âsâri'l- 'Ulviyye ve'l-Felek=Codex Ayasofya 4832: A Collection of Mathematical, Philosophical, Meteorological, and Astromical Treatises, Frankfurt am Main: Institut für Geschichte der arabisch-islamischen Wissenschaften an der Johann Wolfgang Goethe-Universität, 2010, s. 117-118. 
—_, Risâle fî'l-Kelâl li-Evḥadi'z-Zamân Ebî'l-Berakât eț-Tabîb, Tahran, Şûrâ-yı Millî, nr. 706/2, s.162-163, müst. Abdu'l-Ğanî b. Vecîhi'd-Dîn, Dâru's-Salțana-Kazvin, Raceb 1006/1598.

—, Risâle fî̀l-Melâl li-Evḥadi'z-Zamân Ebî'l-Berakât eț-Ṭabîb, Meşhed, Rażavî, nr. 13134, y. 68b-69a, müst. Muḥammed Rıżâ, Şa bân 1065/Haziran-Temmuz 1655.

\section{Berşe 'așâ}

el-Bağdâdî, Ebû'l-Berakât, Berşe 'aşâ el-Mucerreb li-Ebî'l-Berakât elBağdâdî, İstanbul, Süleymaniye YEK, Ayasofya, nr. 3555/2, y. 39a.

—_, Sıfatu Tiryâki Berşe așâ li-Evhadi'z-Zamân Ebî'l-Berakât, İstanbul, Köprülü YEK, Fâzıl Ahmed Paşa, nr. 985/2, y. 74b, müst. Necmu'dDîn el-Kerhînî, 10 Şa bân 787/16 Eylül 1385.

—_, Sıfatu Berşe 'aşâ el-Mensûb ilâ Evḥadi'z-Zamân Ebî'l-Berakât, Manisa YEK, nr. 1781/6, y. 152b-156a, müst. Zekeriyyâ b. Bilâl el-Merâğî, Bağdat, Raceb 617/Eylül 1220.

, Berşe 'aşâ el-Mucerreb li-Ebî'l-Berakât el-Bağdâdî, Tokyo, Institute of Oriental Culture, Daiber Collection, nr. 113/23, y. 207a-208a, müst. Muhammed Nașîr b. Şâh Ḥuseyn es-Seyyâf et-Tebrîzî, 1062/1652.

12./18. yy

, Şerbetu Berşe aşâ, Tahran, Dânişgâh, nr. 4217/1, y. 1a-2a,

—, Tiryâku Berşe aşâ, Tahran, Melik, nr. 4218/1, s. 1-5, $846 / 1442-43$

—-, Tiryâku Berşe așâ, Tahran, Kitâbhâne-i Huseyn Miftâh, Muhammed Huseyn, nr. 328/5, 3 s., müst. Muhammed el-Mutațabbib, 19 Şevvâl 1246/2 Nisan 1831.

—_, Tiryâku Berşeğşâ li-Evhadi'z-Zamân, Kahire, Dâru'l-Kutubi'lMısriyye, Teymûriyye, nr. 191/4, y. 122a-123a.

$154 b-157 a, 723 / 1323 .{ }^{30}$

30 Nüsha, sayısal çekimi yapılmadan kütüphaneden çalındığı için kayıp durumdadır. Kayıtlı bu yazmaların dışında, Berşe assâ'nın, birisi Osmanlı Türkçesinde kaleme alınmış, diğeri ise Farsça manzum tasvirî çevirileri bulunmaktadır: (1) [Meçhul], Sıfatu Tiryâki Beriş îsâ, İstanbul, Süleymaniye YEK, Ayasofya, 3595/2, y. 174b177a. (2) [Meçhul], [Berşe așâ-yı Manz̦ûm], Tahran, Şûrâ-yı İslâmî, nr. 6264, y. 3b. 


\section{Emînu'l-Ervâh}

el-Bağdâdî, Ebû'l-Berakât, Emînu'l-Ervâh, Manisa YEK, nr. 1781/7, y. 156a-157a, müst. Zekeriyyâ b. Bilâl el-Merâğî, Bağdat, Raceb 617/Eylül 1220. $157 b-159 a{ }^{31}$ Emînu'l-Ervâh, Konya Bölge YEK, Yusuf Ağa, nr. 4983, y.

\section{8. [Tefsîru Kitâbi Kôhelet]}

el-Bağdâdî, Ebû'l-Berakât, Oxford, Bodleian Library, Pococke, nr. 274,177 y.

1767.

\section{Eserlerinin Neşirleri ve Çevirileri}

\section{Neşirler}

el-Bağdâdî, Ebû'l-Berakât, el-Kitâbu'l-Mu'teber fî'l-Hikme, 3 cilt, nşr. Zeynu'l- Âbidîn el-Mûsevî v.dğr., Haydarâbâd: İdâretu Cem iyyeti Dâ'ireti'lMa 'ârifî'l-' Usmâniyye, 1357-58/1938-39. ${ }^{32}$

—, el-Kitâbu'l-Mu'teber fî'l-Hikmeti'l-Ilâhiyye, 3 cilt, nşr. Yûsuf Maḥmûd, Doha [Katar]: Dâru'l-Ḥikme, 1432/2012. ${ }^{33}$

31 Nüsha, sayısal çekimi yapılmadan kütüphaneden çalındığı için kayıp durumdadır.

32 el-Kitâbu'l-Mu'teber'in bu ilk neşrinde İstanbul'dan Haydarabad Âsafiyye Kütüphanesi'ne nakledilen nüsha (صف) esas alınmış; ayrıca Fâzıl Ahmed Paşa 919 (كو), Es'ad Efendi 1931 (سع), Lâleli 2553 (لاع) nüshaları kullanılmıştır. Eserin naşiri olarak pek çok kaynakta Suleymân en-Nedvî ve Şerafettin Yaltkaya gösterilmektedir. Bu yaygın hatanın muhtemel nedeni, neşrin iç kapağında muhakkiklerin isimlerinin anılmaması; bununla birlikte, Nedvî'nin tahkikli metnin sonuna bir makale eklemesi ve tahkik için İstanbul'dan bir nüsha temin eden Yaltkaya'nın isminin tahkik içinde anılması olabilir. Fakat eserin mantık ve ilahiyat ciltlerinin sonuna eklenen açıklamalardan (c. 1, s. 279; c. 3, s. 253), neşri Zeynu'l'Âbidîn el-Mûsevî, 'Abdullâh b. Aḥmed el-'Alevî, Aḥmed b. Muḥammed el-Yemânî ve Muhammed 'Âdil el-Kuddûsî'nin gerçekleştirdiği anlaşılmaktadır. Eserin tıpkıbasımları şöyledir: (1) el-Bağdâdî, el-Kitâbu'l-Mu teber fî'l-Hikme, 3 cilt, nşr. Zeynu'l- Âbidîn el-Mûsevî v.dğr., İsfahan: İntişârât-i Dânişgâh-i İșfahân, 1415/1995. (2) el-Bağdâdî, el-Kitâbu'l-Mu 'teber fî'l-Hikmeti'-Ilâhiyye, 1 cilt içinde 3 cilt, nşr. Zeynu'l- Ẩbidîn el-Mûsevî v.dğr., Cubeyl: Dâr ve Mektebetu Bîblûn, 2005. Yeni dizgi: el-Bağdâdî, el-Kitâbu'l-Mu 'teber fîl'-Hikmeti'l-Ilâhiyye, 1 cilt içinde 3 cilt, nşr. Zeynu'l- Ẩbidîn el-Mûsevî v.dğr., Beyrut: Menşûrâtu'l-Cemel, 2012.

$33 \mathrm{Bu}$ neşir Haydarabad baskısını ve III. Ahmed nr. 3222'de kayıtı nüshanın mikrofilmini kullanmıştır. Bu neşrin kaynağına katkısı, daha iyi bir dizgi ve imla sunmaktan ibarettir. 
—, Kitâbu'I-Mu 'teber fî'l-Hikme, 2 cilt, nşr. Muḥammed 'Ușmân, Kahire: Mektebetu'ś-Sekâfeti'd-Dîniyye, 2015. ${ }^{34}$

Langermann, Yitzhak Tzvi, "A fragment of Abū'l-Barakāt alBaghdādī's al-Kitāb al-Mu 'tabar', Kiryat Sefer, 61 (1986-87), s. 361-362 [ỉbranca]. ${ }^{35}$

Pines, Shelomo, "Le-Heḳer Peruşo şel Ebû'l-Berakât el-Bağdâdî 'al Sefer Ḳôhelet: Arba 'ah Tekstîm”, Tarbiż, 33:2 (1963), s.198-213. ${ }^{36}$

Poznanski, Samuel, "Mitteilungen aus Handschriftlichen Bibelkommentaren: Aus Abu-I-Barakât Hibat-Allah's arabischem Kommentar zu Kohelet", Zeitschrift für hebraeische Bibliographie, 16 (1913), s. 32-36. ${ }^{37}$

eț-Ṭayyib, Aḥmed Muḥammed, "Un traité d’Abū I-Barakāt al-Bag̉dādī sur l'intellect: Kitāb Șahīh Adillat al-Naql fĩ Māhiyyat al- 'Aql', Annales Islamologiques, 16 (1980), s. 127-147. ${ }^{38}$

Tunagöz, Tuna, “Ebū'l-Berakāt el-Bag̉dādī'nin Risāle fì Māhiyyeti’Melāl Adlı Eseri: İnceleme, Eleştirel Metin ve Çeviri”, Ankara Üniversitesi IIlahiyat Fakültesi Dergisi, 57:2 (2016), s. 1-45.

34 Bu neşir metin olarak Haydarabad baskısını kullanmış, herhangi bir yazmayı esas almamıştır. Naşirin dayandığı metne katkısı, yer yer dipnotlarda açıklamalar yapmak, daha iyi bir dizgi ve imla sunmaktan ibarettir.

35 Bu makalede el-Kitâbu'l-Mu'teber'in İbranî harfleriyle yazılmış Arapça metninin birkaç pasajı neşredilmiştir. Tıpkıbasım: Langermann, Y. Tzvi, "A fragment of Abū al-Barakāt al-Baghdādī's al-Kitāb al-Mu'tabar", Mi-ginze ha-Makhon le-tatslume kitve ha-yad ha-'Ivriyim, ed. Avraham David, Kudüs: Bet ha-sefarim ha-le'umi vehauniversita'i, 1995, s. 50-51.

36 Makale, Bağdâdî'nin Kôhelet Şerhi'nin dört seçme metni ve bu metinler üzerine bir incelemedir. Tıpkıbasım: Pines, Shlomo, "Le-Heker Peruşo şel Ebû'l-Berakât elBağdâdî 'al Sefer Kôhelet: Arba'ah Tekstîm”, Beyn Mahşevet Yisra'îl li-Mahşevet ha-'Amîm: Mehkarîm be-Toldot ha-filosofyah ha-Yehudit, Kudüs: Mosad Bialîk, 1977, s. 68-83. Bağdâdî̀nin bu eserinin tenkitli tam metninin ve İngilizce tercümesinin yayıma hazırlandığı ifade edilmektedir: Robinson, James T., $A b \bar{u}$ alBarakāt al-Baghdādī's Commentary on Qohelet: Edition of the Judeo-Arabic Text with English Translation and Introduction,

https://divinity.uchicago.edu/sites/default/files/imce/pdfs/

CVs/james\%20robinson\%252c\%20cv\% 202015.pdf (Erişim: 06.03.2017).

Makale, Bağdâdî'nin Kôhelet Şerhi'nde yer alan birkaç pasajın neşridir.

38 Makalede, Bağdâdînnin akıl risalesi hakkında bilgilere yer verilmiş ve bilinen tek nüshasının (Leipzig, Vollers, nr. 882/1) tahkiki yapılmıştır. Muhakkikin isim tercihi, mecmuanın iç kapak sayfasındaki ibareye dayanmaktadır (y. 1a). Metnin girişinde ise eser Risâle fí'- 'Akl ve Mâhiyyetih adıyla anılmaktadır (y. 1b). 
—_, "İslam Bilim Tarihinden Bir Sayfa: Risâle fî sebebi zuhûri'lkevâkib leylen ve hafâiha nehâran (Inceleme, Tenkitli Metin ve Çeviri)", Dîvân: Disiplinlerarası Çalışmalar Dergisi, 20:38 (2015/1), s. 39-82.

Wan Abdullah, Wan Suhaimi, "The Arabic Text", Abū al-Barakāt's Psychology: Critical Edition of the Section on Soul (al-Nafs) from al-Mu'tabar fi al-Hikmah with Analysis and Translation of Selected Texts, Doktora Tezi, Kuala Lumpur: International Islamic University, International Institute of Islamic Thought and Civilization, 2007, s. 178-510. ${ }^{39}$

—_, "Nașșu'l-Mu 'teber fî̀l-Hikme: K়ısmu'l- 'Illmi'l-İlâhî”, el-Illâhiyyât mine'l-Mu 'teber li-Ebî'l-Berakât el-Bağdâdî: Tahkị̣̂ ve Dirâse, Yüksek Lisans Tezi, Kahire: Câmi 'atu'l-Kâhira, 1998, s. 202-550.

\section{2. Çeviriler}

Binti Muhammad, Zarina, The Heavenly Phenomena: A Study of Abū'l-Barakāt al-Baghdādī's Kitāb al-Mu'tabar, Yüksek Lisans Tezi, Kuala Lumpur: International Institute of Islamic Thought and Civilization, 2003, s. 1442.40

Gökmen, Fatin, "Yıldızların Gece Görünüp de Gündüz Görünmemesi Hakkında Şeyhürreis İbni Ali Sina'nın Risâlesi”, Büyük Türk Filozof ve Tıb Üstadı Ibni Sina: Şahsiyeti ve Eserleri Hakkında Tetkikler, İstanbul: Türk Tarih Kurumu Yayınları, 1937, s. 1-4. ${ }^{41}$

39 Tezin ilk bölümünde Bağdâdî'nin nefs teorisi incelenmiştir (s. 11-122). İkinci bölümde el-Kitâbu'l-Mu'teber'in nefs bahsinin birinci, ikinci, altıncı, onuncu ve on beşinci fasılları İngilizceye çevrilmiştir. Üçüncü ve son bölümde ise nefs bahsinin tümü tahkik edilmiştir. Bu tezin ve Bağdâdî'nin nefs anlayışı ile ilgili bir çalışmanın iki ayrı kitap olarak yayıma hazırlandığı ifade edilmektedir: Wan Abdullah, W. S., Abū al-Barakāt on Soul: A Critical Edition of Section on Soul from al-Mu tabar fĩ alHikmah with an Annotated Summary; Abū al-Barakāt el-Baghdādī's Psychology, http://www.kalamresearch.com/ kalamres/article.php?artID=48 (Erişim: 01.04.2017).

40 Tezin dört bölümünde, el-Kitâbu'l-Mu'teber'in fizik bölümünün ikinci cüz'ünün dört faslının $(3-5,8)$ İngilizce çevirisine yer verilmiştir.

41 Daha önce bahsedildiği üzere, Bağdâdî'nin Risâle fî Sebebi Zuhûri'l-Zevâkib Leylen ve Hafâ' iha Nehâran isimli eseri, çeşitli nüshalarda farklı isimle İbn Sînâ'ya atfedilmiştir. Kullandığı nüshalara binaen eseri İbn Sînâ'ya atfeden Gökmen'in çevirisi, yazar ve eser ismindeki yanlışlığa rağmen, gerçekte Bağdâdî külliyatına dâhildir. Çalışmanın yeni bir baskısı bulunmaktadır: Gökmen, Fatin, "Yıldızların Gece Görünüp de Gündüz Görünmemesi Hakkında Şeyhürreis İbni Ali Sina'nın Risalesi", Büyük Türk Filozof ve Tıp Üstadı Ibni Şina: Şahsiyeti ve Eserleri Hakkında Tetkikler, Ankara: Türk Tarih Kurumu Yayınları, 2014, s. 861-865. 
Nasir, Ahmad Malki, Some Aspects of Abū al-Barakāt al-Baghdādī's Metaphysics: A Partial Translation of Kitāb al-Mu tabar with Introduction, Doktora Tezi, Kuala Lumpur: Islamic Thought and Civilization, International Islamic University Malaysia, $2011 .{ }^{42}$

Nony, Sylvie, "Traduction de la Physique du Kitāb al-Mu 'tabar", Abū lBarakāt al-Baǵdādī: une théorie physique de la variation du mouvement au XIle siècle, à Bagdad içinde, Doktora Tezi, Paris: Université Paris-Diderot, Histoire et Philosophie des Sciences, 2010, s. 389-498. ${ }^{43}$

Özpilavcı, Ferruh, “Ebü'l-Berekât el-Bağdadi: Sahîhi Edilleti'n-Nakl fî Mâhiyyeti'l-Akl: Akıl Riselesi”, İslâmî Illimler Dergisi, 5:2 (2010), s. 247-261.44

Rashed, Roshdi, "Fragment of al-Mu'tabar fĩ al-hikma of Abū alBarakāt al-Baghdādī", Geometry and Dioptrics in Classical Islam, London: AlFurqān Islamic Heritage Foundation, 1426/2005, s. 990.45

Rosenthal, Franz, "Die Naturwissenschaft", Das Fortleben der Antike im Islam, Zürih: Artemis Verlag, 1965, s. 224-242.46

Ünver, Ahmet Süheyl, "Avicenna Explains Why Stars Are Visible at Night and Not During the Day", Journal of the History of Medicine and Allied Sciences, $1: 2$ (1946), s. 330-334. ${ }^{47}$

42 Bu tezi temin edemedim; fakat isminden el-Kitâbu'l-Mu'teber'in ilahiyat bölümünün kısmî çevirisine yer verdiği anlaşılmaktadır.

43 Bağdâdînnin hareket kuramını inceleyen tezin dokuzuncu ve sonuncu bölümünde, el-Kitâbu'l-Mu 'teber'in fizik bölümünün birinci cüz'ündeki on altı faslın (4, 10-18, 2328) Fransızca tercümesine yer verilmiştir.

44 Makale Aḥmed M. eț-Ṭayyib tarafından neşredilen akıl risalesinin Türkçe çevirisidir.

45 Kitapta, el-Kitâbu'l-Mu'teber'in fizik bölümündeki küçük bir pasajın (1939: c. 2, s. 97) Arapça metnine ve İngilizce çevirisine yer verilmiştir.

46 Kitapta, el-Kitâbu'l-Mu'teber'in fizik bölümünün birinci cüz'ünün birinci faslının ikinci yarısı ile (fiziğin konusu), dokuzuncu (hareket) ve on üçüncü (boşluk) fasıllarının tamamı Almancaya çevrilmiştir. Kitabın İngilizce çevirisi de bulunmaktadır: Rosenthal, Franz, "Natural Science", The Classical Heritage in Islam, çev. Emile \& Jenny Marmorstein, New York: Routledge, 1992, s. 163-176.

47 Gökmen'in çalışmasında olduğu gibi, kullandığı nüshaya (Ayasofya 4832/13) binaen eseri İbn Sînâ'ya atfeden Ünver, öncelikle risale hakkında kısa bilgiler vermiş; ardından eseri serbest ve tasvirî biçimde İngilizceye çevirmiştir. Yazar ve eser ismindeki yanlışlığa rağmen, bu çalışma da Bağdâdî külliyatına dâhildir. Yazar daha sonra aynı çalışmayı Türkçe yayımlamıştır: Ünver, A. Süheyl, "İbni Sinanın, Yıldızların Gece Görünüp Gündüz Görülmemeleri Hakkındaki Makalesi”, Ibni Sina: Hayatı ve Eserleri Hakkında Çalışmalar, İstanbul: Bürhaneddin Erenler Matbaası, 1955, s. 106-110. 
Wiedemann, E[ilhard], "Ueber den Grund, aus dem die Sterne bei Nacht sichtbar und bei Tage verborgen sind, von Hibbat Allâh Ibn Malkâ al Jehûdî al Bagdâdî”, Jahrbuch der Photographie und Reproduktionstechnik, 23 (1909), s. 49-54. ${ }^{48}$

[Yaltkaya], M. Şerefeddin, Ilâhiyat: (Bağdat) Iı Ebulberekât Namındaki Feylesofun [Kitabülmuteber] inin Üçüncü Kısmının Tercemesini Muhtevidir, İstanbul: Bürhanettin Matbaası, 1932. ${ }^{49}$

\section{Hayatını ve Eserlerini Konu Edinen Eserler}

\section{Klasik Eserler}

el-Beyhakîi, Zahîru'd-Dîn, "el-Feylesûf Evḥadu'z-Zamân Ebû'l-Berakât b. Melkâ(n) eț-Ṭabîb”, Târîhu Hukemâ'i'l-İslâm, nşr. Muhammed Kurd 'Alî, Şam: Mațba 'atu't-Teraḳkî bi-Dimeşḳ, 1365/1946, s. 152-154. ${ }^{50}$

48 Bağdâdî'nin Risâle fî Sebebi Zuhûri'l-Kevâkib Leylen ve Hafâ'iha Nehâran isimli eserinin Berlin Milli Kütüphanesi'ndeki nüshasına (nr. 466/8) dayanan makale, giriş mahiyetinde bazı bilgilerle risalenin serbest ve özet bir biçimde Almancaya çevirisini intiva etmektedir. Makalenin tıpkıbasımları: (1) Wiedemann, Eilhard, "Ueber den Grund, aus dem die Sterne bei Nacht sichtbar und bei Tage verborgen sind, von Hibbat Allâh Ibn Malkâ al Jehûdî al Bagdâdî", Gesammelte Schriften zur arabisch-islamischen Wissenschaftsgeschichte, ed. Dorothea Girke, Frankfurt am Main: Institute for the History of Arabic-Islamic Science at the Johann Wolfgang Goethe University, 1984, c. 1, s. 348-353. (2) Wiedemann, Eilhard, "Ueber den Grund, aus dem die Sterne bei Nacht sichtbar und bei Tage verborgen sind, von Hibbat Allâh Ibn Malkâ al Jehûdî al Bagdâdî”, Natural Sciences in Islam, Optics: Texts and Studies III, ed. Fuat Sezgin, Frankfurt am Main: Institute for the History of Arabic-Islamic Science at the Johann Wolfgang Goethe University, 2001, s. 113118.

49 Kitapta öncelikle Bağdâdî'nin hayatına ve eserlerine yönelik bilgiler verilmiş, ardından el-Kitâbu'l-Mu'teber'in ilahiyat cildinin önemli bir kısmı tasvirî biçimde tercüme edilmiştir. Kitap, Yaltkaya'nın farklı zamanlarda ve farklı isimlerle yayımlanan altı ayrı makalesinin birleştirilmiş halidir: (1) Şerafeddin, M., "Ebu alBerekât al-Bağdadî: Hayatı, İlâhiyat", Darülfünun Illahiyat Fakültesi Mecmuası: Tarihî, İçtimaî, Dinî, Felsefî, 4:17 (1930), s. 25-41. (2) Şerafeddin, M., "[Başlıksız]", Darülfünun Illâhıyat Fakültesi Mecmuası: Tarihî, lç̧timaî, Dinî, Felsefî, 5:18 (1931), s. 1-15. (3) [M. Şerefeddin], "Kitbul-Mu'teber", Darülfünun Ilâhiyat Fakültesi Mecmuası: Tarihî, İctimaî, Dinî, Felsefî, 5:19 (1931), s. 1-16. (4) Şerafeddin, M., "Kitâb al-Mu'teber", Darülfünun Illâhiyat Fakültesi Mecmuası: Tarihî, İctimaî, Dinî, Felsefî, 5:20 (1931), s. 1-16. (5) Şerafeddin, M., "Kitap al-muteber", Darülfünun Ilâhiyat Fakültesi Mecmuası: Tarihî, lçtimaî, Dinî, Felsefî, 5:21 (1931), s. 1-16. (6) Şerafeddin, M., "Kitap-al-muteber", Darülfünun Ilâhıyat Fakültesi Mecmuası: Tarihî, İçtimaî, Dinî, Felsefî, 5:22 (1931), s. 14-26.

50 Diğer baskılar: (1) el-Beyhakî, Zahîru'd-Dîn, "el-Feylesûf Evḥadu'z-Zamân Ebû'lBerakât b. Melkâ eț-Ṭabîb", Kitâbu Tetimmeti Șıvâni'l-Hikme, nşr. Muhammed Şefî', Lahor: b.b., 1351/1932, s. 150-153. (2) el-Beyhaḳî, Zahîru'd-Dîn, "Evhadu'z- 
Ebû'l-Fidâ', 'İmâdu'd-Dîn, "Evḥadu'z-Zamân Ebû'l-Berakât Hibetullâh b. Melkân el-Hakîm”, el-Muhtasar fî Ahbâri'l-Beşer, nşr. Maḥmûd Deyyûb, Beyrut: Dâru'l-Kutubi'l- 'Illmiyye, 1417/1197, c. 2, s. 118. ${ }^{51}$

el-Ğazzûlî, 'Alâ'u'd-Dîn, "Evḥadu'z-Zamân Hibetullâh Ebû'l-Berakât", Mețâli 'u'I-Budûr fî Menâzili's-Surûr, [Kahire]: Mațba atu İdârati'l-Vațan, 12991300 , c. 2 , s. $105-106$.

İbn Ebî Ușaybi'a, "Evḥadu'z-Zamân Ebû'I-Berakât Hibetullâh b. 'Alî b. Melkâ”, 'Uyûnu'l-Enbâ' fî Tabakâti'l-Ețıbbâ', nşr. Nizâr Rıḍ̂a, Beyrut: Dâru Mektebeti'l-Hayât, t.y., s. 374-376. ${ }^{52}$

İbn Hallikân, "Hibetullâh b. 'Alî b. Melkân", Vefeyâtu'l-A yân ve Enbâ'u Ebnâ'i'z-Zamân, nşr. Ị̇sân 'Abbâs, Beyrut: Dâru Șâdır, 1397/1977, c. 6, s. 74-75.

İbnu'l- '̇̉brî, Ebû'l-Ferac, Târîhu Muhtasari'd-Duvel, nşr. Anțûn Șâlihânî el-Yesû 'î, Beyrut: Dâru'r-Râ'idi'l-Lubnânî, 1403/1983, s. 360-366.

Kâtib Çelebî, “el-Mu'teber fî̀l-Mantıḳ”, Keşfu'z-Zunûn 'an Esâmî'lKutub ve'l-Funûn, nşr. Şerefeddin Yaltkaya \& Kilisli Muallim Rifat, İstanbul: Maârif Matbaası, 1941, c. 2, s. $1731 .^{53}$

el-Ḳıfțî, Cemâlu'd-Dîn, "Hibetullâh b. Melkâ", Ihbâru'l-'Ulemâ' biAhbâri'l-Hukemâ', nşr. İbrâhîm Şemsu'd-Dîn, Beyrut: Dâru'l-Kutubi'l- 'İlmiyye, 1426/2005, s. 256-259. ${ }^{54}$

Zamân Ebû'l-Berakât b. Melkâ el-Bağdâdî", Tetimmetu Șıvâni'l-Hikme, nşr. Rafîk el- 'Acem, Beyrut: Dâru'l-Fikri'l-Lubnânî, 1994, s. 125-127. (3) el-Beyhaḳ̂i, Zahîru'dDîn, "el-Feylesûf Evḥadu'z-Zamân Ebû'l-Berakât b. Melkân eț-Tabîb", Târîhu Hukemâ'i'l-ìslâm, nşr. Memdûh Hasen Muhammed, Kahire: Mektebetu'śSekâfeti'd-Dîniyye, 1417/1996, s. 171-172. Eserin 14. yüzyılda yapılmış bir Farsça tercümesi de bulunmaktadır: el-Beyhakîi, Zahîru'd-Dîn, "el-Feylesûf Evḥadu'zZamân Ebû'l-Berakât b. Melkâ el-Bağdâdî", Durretu'l-Ahbâr ve Lem 'atu'l-Envâr, çev. Nâșıru'd-Dîn b. 'Umdeti'l-Mulk el-Yezdî, nşr. 'Alî Evcubî, Tahran: Mu'essese-i İntişârat-ı Hikmet, 1388 hş./2009-10, s. 91-93.

51 Diğer baskı: Ebû'l-Fidâ', 'İmâdu'd-Dîn, "Evhadu'z-Zamân Ebû'l-Berakât Hibetullâh b. Melkân el-Hakîm”, el-Muhtasar fî Ahbâri'l-Beşer, [Kahire]: el-Mațba'atu'lHuseyniyyetu'l-Mıșriyye, t.y., c. 3, s. 43.

52 Diğer baskı: (1) İbn Ebî Ușaybi a, "Evḥadu'z-Zamân Ebû'l-Berakât Hibetullâh b. 'Alî b. Melkâ", Kitâbu 'uyûnu'I-Enbâ' fî Țabakâti'l-Ețıbbâ', nşr. İmri' u'I-Kays eț-Ṭaḥhân (August Müller), [Kahire]: el-Mațba 'atu'I-Vehbiyye, 1299/1883, s. 278-280.

53 Diğer baskı: Kâtib Çelebî, "Mu'teber fî'l-Mantıḳ", Keşfu'ž-Ẓunûn 'an Esâmî'l-Kutub ve'l-Funûn: Lexicon Bibliographicum et Encyclopaedicum, nşr. Gustavus Fluegel, Leipzig: Oriental Translation Fund of Great Britain and Ireland, 1850, c. 5, s. 620.

54 Diğer baskılar: (1) el-Ḳıfțî, Cemâlu'd-Dîn, "Hibetullâh b. Melkâ Ebû'l-Berekât”, Ibn al-Qifti's Ta'rīh al-Hukamā', nşr. Julius Lippert, Leipzig: Dieterich'sche 
[Meçhul], “el-Feylesûf Evḥadu'z-Zamân Ebû'l-Berakât b. Melkâ elBağdâdî”, Muhtasar fî Zikri'l-Hukemâ'i'l-Yûnâniyyîn ve'l-Milliyyîn, Madrid, Real Biblioteca del Monasterio de El Escorial, Arabes, nr. 635, y. 61a.

el-'Umerî, İbn Faḍlullâh, "Evḥadu'z-Zamân, Ebû'l-Berakât Hibetullâh b. 'Alî b. Melkâ el-Beledî”, Mesâliku'l-Ebșâr fî Memâliki'l-Emșâr, nşr. Kâmil Selmân el-Cubûrî, Beyrut: Dâru'l-Kutubi'l- 'Illmiyye, 2010, c. 9, s. 247-250.55

eș-Ṣafedî, Halîl b. Aybek, "Evḥadu'z-Zamân eț-Tabîb”, el-Vâfî bi’lVefeyât, nşr. Aḥmed el-Arna' ûț \& Turkî Mușțafâ, Beyrut: Dâru İḥâ'i't'-Turâși'l'Arabî, 1420/2000, c. 27, s. 178.56

—, "Hibetullâh b. 'Alî b. Melkâ Ebû'l-Berakât Evḥadu'z-Zamân", Nekșu'l-Himyân fî Nuketi'l- 'Umyân, nşr. Mușțafâ 'Abdu'l-Kâadir 'Ațâ, Beyrut: Dâru'l-Kutubi'l- 'Illmiyye, 1428/2007, s. 289-290. 57

eş-Şehrazûrî, Şemsu'd-Dîn, “Ebû'l-Berakât el-Bağdâdî”, Nuzhetu’lErvâh: Bilgelerin Tarihi ve Özdeyişleri, nşr. ve çev. Eşref Altaş, İstanbul: Türkiye Yazma Eserleri Kurumu Başkanlığı Yayınları, 2016, s. 794-797. ${ }^{58}$

el-Vațvâț, Raşîdu'd-Dîn, “Kitâb ilâ'l-Hakîm el- Âlim Ebî'l-Berakât ețTabîb el-Bağdâdî mine'l-Haḍrati'l-Hârizmşâhiyye”, Mecmû'atu Rasâ'ili Raşîdi'd-Dîn el-Vațvât, nşr. Muḥammed Efendî Fehmî, [Kahire]: Matba 'atu'lMa ârif, 1315, c. 1, s. 64-65.

ež-ZZehebî, Şemsu'd-Dîn, "Ebû'l-Berakât Hibetullâh b. 'Alî b. Melkâ elBeledî”, Siyeru A'lâmi'n-Nubelâ', nşr. Şu'ayb el-Arna'ût v.dğr., Beyrut: Mu'essesetu'r-Risâle, 1405/1985, c. 20, s. 419. ${ }^{59}$

Verlagsbuchhandlung, 1903, s. 343-346. (2) Kııfțî, Cemâlu'd-Dîn, "Hibetullâh b. Melkâ", Kitâbu Ihbâru'l-'Ulemâ' bi-Ahbâri'l-Hukemâ', nşr. Muḥammed Emîn elHâncî, Mısır: Mațba'atu's-Sa'âde, 1326/1908-09, s. 224-227.

55 Diğer baskı: el-'Umerî, İbn Faḍlullâh, "Evḥadu'z-Zamân, Ebû'l-Berakât Hibetullâh b. 'Alî b. Melkâ el-Beledî", Mesâliku'l-Ebșâr fî Memâliki'l-Emșâr, Abu Dabi: elMecma 'u's- Sekâfî, 1423/2003, c. 9, s. 452-456.

56 Diğer baskı: eș-Ṣafedî, Halîl b. Aybek, "Evḥadu'z-Zamân eț-Ṭabîb”, Kitâbu'l-Vâfî bi'l-vefeyât, nşr. Otfried Weintritt, Beyrut: Mațba atu'ş-Şeriketi'l-Muttahı̣ıde li'tTevzî́, 1418/1997, c. 6/27, s. 300-302.

57 Diğer baskı: eș-Ṣafedî, Halîl b. Aybek, "Hibetullâh b. 'Alî b. Melkâ' Ebû'l-Berakât [Evhadu'z-Zamân] eț-Ṭabîb el-Faḍıl", Nektu'l-Himyân fî Nuketi'l-'Umyân, Mısır: elMațba 'atu'l-Cemâliyye, 1329/1911, s. 304.

58 Diğer baskı: eş-Şehrazûrî, Şemsu'd-Dîn, "Ebû'l-Berakât el-Bağdâdî", Târîhu'lHukema': Nuzhetu'l-Ervâh ve Ravḍatu'l-Efrâh, nşr. 'Abdu'l-Kerîm Ebû Şuveyrib, Trablus: Cem 'iyyetu'd-Da 'veti'l-İslâmiyyeti'l- Âlemiyye, 1398/1988, s. 343-344.

59 Diğer baskı: ež-ZZehebî, Şemsu'd-Dîn, "Ebû'l-Berakât”, Siyeru A'lâmi'n-Nubelâ', Kahire: Dâru'l-Hadîs, 1427/2006, c. 15, s. 168. 
—_, "Ebû'l-Berakât", Tehżîbu Siyeri A 'lâmi'n-Nubelâ', nşr. Şu'ayb el-Arna' ût v.dğr., Beyrut: Mu'essesetu'r-Risâle, 1412/1991, c. 3, s. 55.

—-, "Evḥadu'z-Zamân eț-Ṭabîb", Târîhu'I-Islâm ve Vefeyâtu'lMeşâhîr ve'l-A'lâm, nşr. 'Umer 'Abdu's-Selâm Tedmurî, Beyrut: Dâru'lKitâbi'l-'Arabî, 1413/1993, c. 38, s. 340-342.

\section{Muasır Kaynaklar}

Ağırakça, Ahmet, "Evhadü'z-zaman Ebu'l-Berekât", İslâm Tıp Tarihi (Başlangıçtan VII./XIII. Yüzyıla Kadar), İstanbul: Nobel Tıp Kitapevleri, 2004, s. 234-237.

'Akkâvî, Ruhâab Hıḍ̂r, "íbn Melkâ el-Beledî (t.560 h./1172 m.)", elMûcez fî Târîhi'ț-Ṭıb 'inde'l-'Arab, Beyrut: Dâru'l-Menâhil, t.y., s. 228231. 'Atıyyetullâh, Aḥmed, "Evḥadu'z-Zamân", el-Kâmûsu"l-Islâmî, Kahire: Mektebetu'n-Naḥ̣ati'I-Mıșriyye, 1963, c. 1, s. 212.

el-Bağdâdî, İsmâ'îl Bâşâ, "ibn Melkâ el-Beledî”, Hediyyetu'l- Ârifîn: Esmâ'u'l-Mu'ellifîn ve Âșâru'l-Mușannifîn, nşr. Rifat Bilge v.dğr., Ankara: Millî Eğitim Bakanlı̆̆ı, 1955, c. 2, s. 505-506.60

Brockelmann, Carl, "Auḥadazzamān Hibatallāh 'A. b. Malkā a.'IBarakāt al-Bag̉dādī al-Baladī”, Geschichte der arabischen Litteratur, Leiden: E. J. Brill, 1943, c. 1, s. 602.

- , "Auḥadazzamān Hibatallāh 'A. b. Malkā a.'I-Barakāt alBag̉dādī al-Baladī”, Geschichte der arabischen Litteratur: Supplementband, Leiden: E. J. Brill, 1943, c. 1, s. 831.

—_, "Hibatallâh b. Malka abû 'I Barakât al Bag̉dâdî", Geschichte der arabischen Litteratur, Weimar: Verlag von Emil Felber, 1898, c. 1, s. 460.

el-Cezzâr, Fikrî, "Evḥadu'z-Zamân", Medâhilu'l-Mu'ellifîn ve'l-A'lâm el-'Arab hattâ 'Âm 1215 h.=1800 m., Riyad: Mektebetu'l-Melik Fehd elVațaniyye, 1411/1991, c. 1, s. 117-118.

Daiber, Hans, "Abū I-Barakāt al-Bagdādī", Bibliography of Islamic Philosophy, II: Index of Names, Terms and Topics, Leiden \& Boston \& Köln: Brill, 1999, s. 9.

60 Tıpkıbasım: el-Bağdâdî, İsmâ'îl Bâşâ, “ỉbn Melkâ el-Beledî”, Hediyyetu'l- Ârifîn: Esmâ'u'l-Mu'ellifîn ve Âsâru'l-Mușannifîn, nşr. Rifat Bilge v.dğr., Lübnan: Dâru İhyâ'i't-Turâsis'l- 'Arabî, t.y., c. 2, s. 505-506. 
ed-Deffâ', 'Alî 'Abdullâh, "Hibetullâh b. Melkâ el-Bağdâdî", A 'lâmu'l'Arab ve'l-Muslimîn fî'ț-Tıbb, Beyrut: Mu'essesetu'r-Risâle, 1983, s. 168-176.

Dirâyetî, Mușțafâ, "el-Mu'teber", Fihristvâre-i Destneveşthâ-i Îrân (Denâ), Tahran: İntişârât-ı Kitâbhâne-i Meclis-i Şûrâ-yı İslâmî, 1389 hş./2010, c. 9 , s. 838 .

Dirâyetî, Mușțafâ \& Dirâyetî, Muctebâ, "Tiryâḳu Berşe'aşâ", Fihristgân-i Nushahâ-i Hatțîi Îrân (Fehnâ), Tahran: Sâzmân-ı Esnâd ve Kitâbhâne-i Millî-i Cumhûrî-i İslâmî-i Îrân, 1390 hş./2011, c. 8, s. 162-163.

Fernini, Ilias, "Barakāt (Abū'l-Barakāt)", A Bibliography of Scholars in Medieval Islam: 150-1000 A.H. (750-1600 A.D.), Abu Dabi: Cultural Foundation, 1998, s. 34-35.

İhsanoğlu, Ekmeleddin \& Rosenfeld, Boris A., "Hibatallah al-Baladi alBaghdadi", Mathematicians, Astronomers and Other Scholars of Islamic Civilization and Their Works (7th-19th c.), İstanbul: Ircica Publications, 2003, s. 184.

Karabulut, Ali Rıza \& Karabulut, Ahmet Turan, "Hibetullâh b. 'Alî b. Melkâ", Mu'cemu't-Târîhi't-Turâsi'l-İslâmî fî Mektebâti'l-'Âlem: el-Mahțûtât ve'l-Mațbû ât, Kayseri: Mektebe Yayınları, t.y., c. 5, s. 3874.

Karabulut, Ali Rıza, "Hibetullâh b. 'Alî b. Melkâ", Mu'cemu'lMahțuttâti'l-Mevcûde fî Mektebâti İstânbûl ve Anâțûlî, Kayseri: Akabe Kitabevi, t.y., c. 3, s. 1630-1631.

Keḥhâle, 'Umer Rıḍâ, "Hibetullâh Evḥadu'z-Zamân”, Mu'cemu’lMu'ellifîn, Beyrut: Mu'essesetu'r-Risâle, 1414/1993, c. 4, s. 59. ${ }^{61}$

Leclerc, Lucien, "Aboul Barakat Aouhad Ezzeman”, Histoire de la médecine arabe: Exposé complet des traductions du grec; les sciences en Orient, leur transmission à l'Occident par les traductions latines, Paris: Ernest Ledoux, 1876, c. 2, s. 29-31.

Pines, Shlomo, "Abu'l-Barakāt al-Baghdādī, Hibat Allah", Dictionary of Scientific Biography, ed. Charles Coulston Gillispie, New York: Charles Scribner's Sons, 1970 , c. 1 , s. 26-28.

es-Sâmerrâ'î, Kemâl, "Ebû'l-Berekât b. Melkâ al-Beledî”, Muhtașaru Târîhi'ț-Tıbbi'l- 'Arabî, Beyrut: Dâru'n-Niḍâl, 1409/1989, c. 1, s. 527-530.

61 Diğer baskı: Keḥhâle, 'Umer Rıḍ̂, "Hibetullâh Evḥadu'z-Zamân”, Mu 'cemu’Mu'ellifîn, Beyrut: Mektebetu'l-Musennâ \& Dâru İhyâ'i't-Turâsi'l-'Arabî, t.y., c. 13, s. 142-143. 
Sarton, George Alfred Leon, "Hibatallāh ibn Malkā", Introduction to the History of Science: From Rabbi ben Ezra to Roger Bacon, Baltimore: The Williams \& Wilkins Company, 1931, c. 2/1, s. 382.62

Sezgin, Fuat, "Abu I-Barakāt Hibatallāh b. 'Alī b. Malkā al-Bag̉dādī”, Geschichte des arabischen Schrifttums, Leiden: E. J. Brill, 1979, c. 7, s. 215.

Steinschneider, Moritz, "Abu'l-Barakat Hibat Allah b. Ali (Eli?) b. Malka (od. Malkan) al-Baladi”, Die arabische Literatur der Juden, Frankfurt: J. Kauffmann, 1902, s. 182-186.

Suter, Heinrich, "Hibetallâh b. 'Alî b. Melkâ, Abû'l-Barakât, el-Beledî", Die Mathematiker und Astronomen der Araber und Ihre Worke, Leipzig: Druck und Verlag von B. G. Teubner, 1900, s. 123.63

Şeşen, Ramazan v.dğr., “İbn Melkâ, Evḥadu'z-Zamân Ebû'l-Berakât Hibetullâh b. 'Alî el-Bağdâdî”, Fihrisu Mahțûtati'ț-Tıbbi'l-Islâmî bi'l-Luğati'l'Arabiyye ve't-Turkiyye ve'l-Fârisiyye fî Mektebâti Turkiyâ, İstanbul: IRCICA, 1404/1984, s. 90-91.

Şeşen, Ramazan, “Kitâbu'l-Mu'teber fî'l-Hikme”, Nevâdiru'lMahțûtâti'l- 'Arabiyye fî Mektebâti Turkiyâ, Beyrut: Dâru'l-Kitâbi'l-Cedîd, 1975, c. 1, s. 187.

Tarâbîşî, Cûrc, “Ebû'l-Berakât el-Bağdâdî”, Mu'cemu'l-Felâsife: elFelâsife, el-Menâtıka, el-Mutekellimûn, el-Lâhûtiyyûn, el-Mutașavvifûn, Beyrut: Dâru'ț-Ṭalî'a li'ț-Ṭıbâ'a ve'n-Neşr, 2006, s. 36.

Wüstenfeld, Ferdinand, "Abul-Berakât Hibetallah Ben Ali Melkân Auhad el-Zamân el-Beldi”, Geschichte der arabischen Aerzte und Naturforscher, Göttingen: Vandenhoeck und Ruprecht, 1840, s. 98-99.

ez-Ziriklî, Hayru'd-Dîn, “Evḥadu'z-Zamân”, el-A lâm: Kâmûsu Terâcîm li-Eşheri'r-Ricâl ve'n-Nisâ' mine'l- 'Arab ve'l-Musta 'ribîn ve'l-Musteşrikîn, Beyrut: Dâru'l- 'İlm li'l-Melâyîn, 2002, c. 8, s. 74-75.

62 Tıpkıbasım: Sarton, George Alfred Leon, "Hibatallāh ibn Malkā", Introduction to the History of Science: From Rabbi ben Ezra to Roger Bacon, Baltimore: The Williams \& Wilkins Company, 1962, c. 2/1, s. 382.

63 Tıpkıbasım: Suter, Heinrich, "Hibetallâh b. 'Alî b. Melkâ, Abû'l-Barakât, el-Beledî", Die Mathematiker und Astronomen der Araber und Ihre Worke, London \& New York: Johnson Reprint Corporation, 1972, s. 123. 


\section{Tezler}

Aḥmed, Muḥammed Seyyid Muḥammed, el-itticâhu'l-Işrâkî fî Felsefeti Ebî'l-Berakât el-Bağdâdî, Doktora Tezi, Asyût: Câmi atu Asyûț, 2014.

Alaca, Cengiz, Ebu'l-Berekât el-Bağdâdi'nin Metafizik Düşünceleri, Yüksek Lisans Tezi, Ankara: Ankara Üniversitesi Sosyal Bilimler Enstitüsü, 2001.

Çakır Baş, Derya, Ebu'l-Berekât el-Bağdâdî’nin Din Felsefesi, Yüksek Lisans Tezi, İstanbul: Marmara Üniversitesi Sosyal Bilimler Enstitüsü, 1995.

Dağ, Mehmet, The Philosophy of Abū'l-Barakāt al-Baghdādī with Special Reference to His Concept of Time, Doktora Tezi, Durham: University of Durham, 1970.

Haron, Mohd Fadhil, Teori kejadian alam menurut Abū al-Barakāt alBaghdādī, Yüksek Lisans Tezi, Selangor [Malezya]: Universiti Kebangsaan Malaysia, Fakulti Pengajian Islam, 2009.

Hasen, Șabrî 'Ușmân Muhammed, el-Felsefetu'ț-Ṭabîiiyye ve'lIlâhiyye 'inde Ebî'l-Berakât el-Bağdâdî, Doktora Tezi, Kahire: Câmi'atu'lKâhira, 1982.

Hasâneyn, Rabî' Hasâneyn Muḥammed, el-Cânibu'l-ilâhî beyne Ebî'lBerakât el-Bağdâdî (t: 547h.) ve Ibn Ruşd (t: 595h.): Dirâse Mukârene, Yüksek Lisans Tezi, Kahire: Câmi 'atu'l-Ezher, 2015.

Ğazzâl, 'Abdu'r-Ra'ûf 'Aydârûs 'Alî, Naẓariyyetu's-Sa'âde ve 'Alâkatuhâ bi'l-Fi'li'l-Insânî 'inde Kullin min: Ebû'l-Barakât el-Bağdâdî ve Fahru'd-Dîn er-Râzî, Doktora Tezi, Zekââị̂ [Mısır]: Câmi 'atu'z-Zekââiḳ, 1999.

İbrâhîm, Ni'me Muhammed, Ebû'l-Berakât el-Bağdâdî ve Felsefetuhû't-Tabî'iyye, Yüksek Lisans Tezi, Bağdat: Câmi'atu Bağdâd, 1981.

—_, 'Illmu Mâ-ba'de'ț-țabî‘a fî Felsefeti Ebî̀l-Berakât el-Bağdâdî, Doktora Tezi, Kufe: Câmi 'atu'l-Kûfe, 1995.

Al-Khelaifi, Abd al-Hakeem, The Psychology of Abū al-Barakāt alBaghdādī, Doktora Tezi, Manchester: University of Manchester, 1995.

Lameer, Joep, De Aristotelische Théorie van het Syllogisme in de Logica van Abū I-Barakāt Al-Bag̉dādī, Yüksek Lisans Tezi, Leiden: [Universiteit Leiden], $1986 .{ }^{64}$

64 Bu teze yönelik bilgi için bkz. Daiber, Bibliography of Islamic Philosophy, c. 1, s. 14. 
Mâlullâh, Șalâḥ 'Ușmân Șâliḥ, el-Ḳıyâs ve'l-Burhân: Dirâse fî Mantıḳi Ebî'l-Berakât el-Bağdâdî, Doktora Tezi, Kahire: Câmi 'atu'l-Kâhira, 2002.

Mirzâ, İhsân bint 'Abdu'l-Ğaffâr 'Abdullâh, Ârâ'u Ebî'l-Berakât elBağdâdî el-i' tikâdiyye fîl-liahhiyyât: Dirâse ve Naḳd 'alâ Dav'i 'Akîideti Ehli'sSunne ve'l-Cemâ'a, Yüksek Lisans Tezi, Mekke: Câmi'atu Ummi'l-Ḳurâ, $1415 / 1994$.

Nasrat, Haidar Ali, La théorie de l'émanation chez Avicenne, AlBaghdadi et Sohrawardi, Doktora Tezi, Paris: Université Paris-Sorbonne, 1973.

Okan, Kutlu, Ebu'l-Berekat el-Bağdadi'nin Bilgi Teorisi, Yüksek Lisans Tezi, İstanbul: Marmara Üniversitesi Sosyal Bilimler Enstitüsü, 2015.

Özkan, Yakup, Ebu'l-Berekat el-Bağdadi'nin Tanrı Anlayışı, Yüksek Lisans Tezi, Sakarya: Sakarya Üniversitesi Sosyal Bilimler Enstitüsü, 2010.

Özpilavcı, Ferruh, Ebu'l-Berekât el-Bağdadî'de Nefs Teorisi, Yüksek Lisans Tezi, Marmara Üniversitesi Sosyal Bilimler Enstitüsü, İstanbul, 2000.

—_, Ebü'l-Berekât el-Bağdâdî'de Tabiat Felsefesi, Doktora Tezi, İstanbul: Marmara Üniversitesi Sosyal Bilimler Enstitüsü, 2008.

Pavlov, Moshe M., Abū'l-Barakāt al-Baghdādī: An Introduction to his Metaphysics in the Conception of Existent Being and its Nexus to the Notion of God, Yüksek Lisans Tezi, Kudüs: Hebrew University, 2003.

- The Epistemological and Logical Foundations of the Metaphysics of the Kitāb al-Mu'tabar fî̀-Hikma of Abū'l-Barakāt al-Baghdādī, Doktora Tezi, Kudüs: Hebrew University, 2011.

Er-Rabî'î, Nebe' 'Abdu's-Settâr Câbir, el-Mantık 'inde Ebî'l-Berakât el-Bağdâdî: Dirâse Tahlîliyye, Yüksek Lisans Tezi, Kufe: Câmi'atu'l-Kûfe, 2012.

Rızḳullâh, Îzîs Eyyûb, Muşkiletu'n-Nefsi'l-Insâniyye fî Felsefeti Ebî’lBerakât el-Bağdâdî (íbn Melkâ) ve Mașâdiruhû'l-Yûnâniyye, Yüksek Lisans Tezi, Kahire: Câmi 'atu'l-Kâhira, 1987.

Sâlim, Aḥmed b. Aḥmed, Muşkiletu Ḳıdemi'l- Âlem ve Hudûsih 'inde Ebî'l-Berakât el-Bağdâdî ve Fahri'd-Dîn er-Râzî, Doktora Tezi, Asyûț: Câmi 'atu Asyûț, 2005.

Şehîd, Huseyn Hamze, el-Mevkıfu'n-Naḳî̀ 'inde Ebî'l-Berakât elBağdâdî: Naẓariyyetu'l-Ma 'rife Enmûzecen, Doktora Tezi, Kufe: Câmi'atu'lKûfe, 2012. 
eț-Ṭayyib, Aḥmed Muḥammed, Mevkııfu Ebî̀l-Berakât el-Bağdâdî mine'l-Felsefeti'I-Meşşâ'iyye, Doktora Tezi, Kahire: Câmi 'atu'I-Ezher, 1990.

Tunagöz, Tuna, Ebû'l-Berakât el-Bağdâdî'de Tanrı Düşüncesi, Doktora Tezi, Ankara: Ankara Üniversitesi Sosyal Bilimler Enstitüsü, 2012. 65

\section{Kitaplar}

Ebû Sa'de, Muhammed Huseynî, el-Vucûd ve'l-Hulûd fî Felsefeti Ebî'l-Berakât el-Bağdâdî, Kahire: Mektebetu'l-Usra, 1993.

Echer, Abdu'l-Hakîm, Ebû'l-Berakât el-Bağdâdî: Binâ'u'l-Âlem 'alâ Mesâ'ili'd-Dîn ve'd-Ders fî'l-Huviyye, Beyrut: el-Merkezu'ś-Seḳâfiyyu'l- 'Arabî, 2011.

Hasen, Șabrî 'Ușmân Muhammed, el-Felsefetu'ț-Ṭabîiiyye ve'lIlâhiyye 'inde Ebî'l-Berakât el-Bağdâdî, İskenderiye: Dâru'd-Da've li'ț-Ṭab ve'n-Neşr ve't-Tevzî', 1982.

İbrâhîm, Ni'me Muhammed, Ebû'l-Berakât el-Bağdâdî ve Felsefetuhû'ț-Tabî'iyye, Necef: Dâru'ḍ-Ḍıyâ', 2007.66

—_, 'illmu Mâ-ba'de'ț-țabî'a fî Felsefeti Ebî'l-Berakât el-Bağdâdî, Necef: Dâru'ḍ-Ḍıyâ', 2007.67

'Îdî, Hamîd, Nakd-ı 'Akâyid: Berresî Nazarât-ı Intikâdi-i Ebû'l-Berakât Bağdâdî ber Ârâ ve 'Akâyid-i Felsefî-i Şeyhi'r-Re'îs Ebû 'Alî Sînâ, Hürremâbâd: Eflâk, 1382 hş./2003.

Nony, Sylvie, Les variations du mouvement: Abū al-Barakāt, un physicien à Bagdad (VIe/XI/e siècle), Kahire: Institut Français d'Archéologie Orientale, 2016.68

Pavlov, Moshe M., Abū'l-Barakāt al-Baghdādī's Scientific Philosophy: The Kitāb al-Mu tabar, New York: Routledge, 2017.

65 ISAM'ın İlahiyat Fakülteleri tezler kataloğu veri tabanında Bağdâdî felsefesine yönelik iki ayrı tezin hazırlık aşamasında olduğu ifade edilmektedir: (1) Yeşil, Mustafa, Ebu'l-Berekât el-Bağdâdî'de Eleştiri, Doktora Tezi, Konya: Necmettin Erbakan Üniversitesi Sosyal Bilimler Enstitüsü; (2) Sağlam, Masum, Ebu'l-Berekât el-Bağdâdî'de Illiyet Teorisi, Yüksek Lisans Tezi, İstanbul: Marmara Üniversitesi Sosyal Bilimler Enstitüsü. (http://ktp.isam.org.tr/?url=tezilh/findrecords.php; erişim: 24.03.2017)

66 Çalışma yazarın yüksek lisans tezine dayanmaktadır.

67 Çalışma yazarın doktora tezine dayanmaktadır.

68 Çalışma yazarın doktora tezine dayanmaktadır.

ÇÜiFD, 2017, cilt: 17, sayı: 1, ss. 187-225 
—, Abū'l-Barakāt al-Baghdādī's Metaphysical Philosophy: The Kitāb al-Mu'tabar, New York: Routledge, 2017.

Pines, Shlomo, Nouvelles etudes sur Awhad al-Zamân Abu-I-Barakât al-Baghdâdî, Paris: Librairie Durlacher, 1955. ${ }^{69}$

Seydebî, Cemâl Raceb, Ebû'l-Berakât el-Bağdâdî ve Felsefetuhû'lIllâhiyye: Dirâse li-Mevkııfihî'n-Nakdî min Felsefeti İbn Sînâ, Kahire: Mektebetu Vehbe, 1996.

eț-Tayyib, Aḥmed Muhammed, el-Cânibu'n-Nakdî fî Felsefeti Ebî'lBerakât el-Bağdâdî, Kahire: Dâru'ş-Şurûḳ, 2004. ${ }^{70}$

Tunagöz, Tuna, Ebü'l-Berekât el-Bağdâdî Felsefesinde Tanrı, Ankara: isAM Yayınları, 2017.71

\section{Kitap Bölümleri}

Adamson, Peter, "All Things Considered: Abū I-Barakāt al-Baghdādī", Philosophy in the Islamic World: A History of Philosophy without any Gaps III, Oxford: Oxford University Press, 2016, s. 302-308.

el-Âlûsî, Husâm, "Ebû'l-Berakât el-Bağdâdî", ez-Zamân fî'l-Fikri'd-Dînî ve'l-Felsefî el-kadîm, Beyrut: el-Mu'essesetu'l- 'Arabiyye li'd-Dirâsât ve'nNeşr, 1400/1980, s. 81-86. ${ }^{72}$

Cohn-Sherbok, Dan, "Abu Al-Barakat”, Medieval Jewish Philosophy: An Introduction, London: Routledge, 1996, s. 75-79.

Corbin, Henry, "Abû'l-Barakât al-Baghdâdî", Histoire de la philosophie islamique, [Paris]: Gallimard, 1986, s. 249-253. ${ }^{73}$

69 Tıpkıbasım: Pines, Shlomo, "Nouvelles etudes sur Awhad al-Zamân Abu'l-Barakât al-Baghdâdî", The Collected Works of Shlomo Pines, l: Studies in Abu'l-Barakāt alBaghdādī: Physics and Metaphysics, Kudüs: Magnes Press, Hebrew University \& Leiden: Brill, 1979, s. 96-173.

70 Çalışma yazarın doktora tezine dayanmaktadır.

71 Çalışma yazarın doktora tezine dayanmaktadır.

72 Yeni Baskı: el-Âlûsî, Husâm, "Ebû'l-Berakât el-Bağdâdî", ez-Zamân fî̀l-Fikri'd-Dînî ve'l-Felsefî ve Felsefeti'l- 'Illm, Beyrut: el-Mu'essesetu'l- Arabiyye li'd-Dirâsât ve'nNeşr, 2005, s. 108-113.

73 Çeviriler: (1) Türkçe: Corbin, Henry, "Ebul-Berekât-ul-Bağdadî”, İslâm Felsefesi Tarihi: Başlangıçtan İbn Rüşd'ün Ölümüne, çev. Hüseyin Hatemi, İstanbul: İletişim Yayınları, 2013, c. 1, s. 315-319. (2) İngilizce: Corbin, Henry, "Abu al-Barakat alBaghdadi", History of Islamic Philosophy, çev. Liadain Sherrard \& Philip Sherrard, London \& New York: Kegan Paul International, t.y., s. 177-179. (3) Arapça: Corbin, 
Ebû Rayyân, Muḥammed 'Alî, "Ebû'l-Berakât el-Bağdâdî”, Târîhu'lFikri'l-Felsefî fí'l-İslâm, İskenderiye: Dâru'l-Ma rifeti'l-Câmi 'iyye, 1990, s. 377406.

Gil, Moshe, "Jewish Figures in the Twelfth and the Thirteenth Centuries: Abū'l-Barakāt Hibat Allah b. 'Alī b. Malkā", Jews in Islamic Countries in the Middle Ages, çev. David Strassler, Leiden: Brill, 2004, s. 469-475.

Hasnawi, Ahmad, "Taxinomie topique: La classification thémistéenne des lieux chez Boèce, Averroès et Abū I-Barakāt al-Baghdādī”, Words, Texts and Concepts Cruising the Mediterranean Sea: Studies on the Sources, Contents and Influences of Islamic Civilization and Arabic Philosophy and Science, ed. Rüdiger Arnzen \& Jörn Thielmann, Leuven: Peeters Publishers, 2004, s. 245-257.

Huveydî, Yaḥyâ, "Naḳdu Ebî'l-Berakât el-Bağdâdî li-Naẓariyyeti İbn Sînâ fî'n-Nefs ve'l- 'Akl”, Muhâdararât fî'l-Felsefeti'l-Islâmiyye, Kahire: Mektebetu'n-Naḥdati'l-Mıșriyye, 1965, s. 191-259. ${ }^{74}$

Kaukua, Jari, "Self, Agent, Soul: Abū al-Barakāt al-Baghdādī's Critical Reception of Avicennian Psychology", Subjectivity and Selfhood in Medieval and Early Modern Philosophy, ed. Jari Kaukua \& Tomas Ekenberg, Switzerland: Springer, 2016, s. 75-89.

Baghdādī to Suhrawardī", Self-Awareness in Islamic Philosophy: Avicenna and Beyond, Cambridge, Cambridge University Press, 2015, s. 104-123.

Luțf, Sâmî Nașr, "Ebû'l-Berakât el-Bağdâdî", Nemâżic min Felsefeti'lİslâmiyyîn, Kahire: Mektebetu Sa îd Ra'fet, 1977.

Murâd, Sa î̀d, "Naẓariyyetu's-Sa âde 'inde Ebî'l-Berakât el-Bağdâdî”, ed-Duktûr Tevfîk eț-Tavîl Mufekkiran 'Arabiyyen ve Râ'iden li'l-Felsefeti'lHulukıyye: Buhûs 'anh ve Dirâsât Muhdât ileyh, ed. 'Âțıf el-'Irâḳ̂, Kahire: elMeclisu'l-A 'lâ li'ș-Sekâfe, 1995, s. 281-290.

Nony, Sylvie, "La dynamique d'Abū I-Barakāt: faire le vide pour penser le changement du changement", In the Age of Averroes: Arabic Philo-

Henry, "Ebû'l-Berakât el-Bağdâdî”, Târîhu'l-Felsefeti'-'Arabiyye, çev. Nașîr Muruvve \& Ḥasen Kabîsî, Beyrut: 'Uveydât li'n-Neşr ve'ț-Ṭıâ'a, 1998, s. 268-271.

74 Bu çalışma başka bir eser içerisinde de yayımlanmıştır: Huveydî, Yaḥyâ, "Naḳdu Ebî'l-Berakât el-Bağdâdî li-Naz̧ariyyeti İbn Sînâ fî̀n-Nefs ve'l- 'Akl", Dirâsât fi 'Illmi'lKelâm ve'l-Felsefeti'l-Islâmiyye, Kahire: Dâru'ș-Șekâfe li'ț-Ṭıâ'a ve'n-Neşr, 1977, s. 239-307. 
sophy in the Sixth/Twelfth Century, ed. Peter Adamson, London: The Warburg Institute, 2011, s. 93-116.

- "Two Arabic Theories of Impetus", çev. Peter E. Pormann, Islamic Medical and Scientific Tradition, III: The Physical Sciences: Physics, Astronomy, Geodesy, ed. Peter E. Pormann, London: Routledge, 2011, s. 332.

Pachniak, Katarzyna, "Abū al-Barakāt al-Baghdādī”, Filozofia polityki muzułmańskiej: na podstawie dzieł Abū Hāmida al-Ḡazālego, Varşova: Dia$\log , 2001$.

Pines, Shlomo, "Concluding Remarks", The Collected Works of Shlomo Pines, I: Studies in Abu'l-Barakāt al-Baghdādī: Physics and Metaphysics, Kudüs: Magnes Press, Hebrew University \& Leiden: Brill, 1979, s. 335338.

- "Note on Abu'l-Barakât's Celestial Physics", The Collected Works of Shlomo Pines, I: Studies in Abu'l-Barakāt al-Baghdādī: Physics and Metaphysics, Kudüs: Magnes Press, Hebrew University \& Leiden: Brill, 1979, s. $175-180$.

, "Studies in Abu'l-Barakāt Al-Baghdādī's Poetics and Metaphysics", Scripta Hierosolymitana, VI: Studies in Philosophy, ed. Samuel H. Bergman, Jerusalem: Magnes Press, Hebrew University, 1960, s. 120-198. ${ }^{75}$

Sirat, Colette, "Judah Halevi and Abu-I-Barakāt", A History of Jewish Philosophy in the Middle Ages, Cambridge: Cambridge University Press, 1996, s. 113-140.

Street, Tony, "Arabic Logic: Abū-I-Barakāt al-Bag̉dādī's Logic", Handbook of the History of Logic, I: Greek, Indian and Arabic Logic, ed. Dov N. Gabbay \& John Woods, Amsterdam: Elsevier, 2004, s. 569-571. ${ }^{76}$

Stroumsa, Sarah, "Abū'l-Barakāt al-Bagdādī, The Jews of Medieval Islam: Community, Society, and Identity, ed. Daniel Frank, Leiden: Brill, 1995, s. $186-189$.

75 Tıpkıbasım: Pines, Shlomo, "Studies in Abu'l-Barakāt Al-Baghdādī's Poetics and Metaphysics", The Collected Works of Shlomo Pines, I: Studies in Abu'l-Barakāt alBaghdādī: Physics and Metaphysics, Kudüs: Magnes Press, Hebrew University \& Leiden: Brill, 1979, s. 259-334.

76 Türkçe Çeviri: Street, Tony, "Arapça Mantık: Ebu'l-Berekât el-Bağdâdî'nin Mantığı”, Islam Mantık Tarihi, der. ve çev. Harun Kuşlu, İstanbul: Klasik, 2013, s. 77-80. 
- "On the Maimonidean Controversy in the East: The Role of Abū'l-Barakāt al-Baghdādī", Hebrew and Arabic Studies in Honour of Joshua Blau, Kudüs: Hebrew University, 1993, s. 415-422 [ibranca].

Şeraf, Muḥammed Celâl Ebû'l-Futûh, el-Mežhebu'l-Işrâkîi beyne'lFelsefe ve'd-Dîn fî'l-Fikri'l-İslâmî, Kahire: Dâru'l-Ma ârif, 1972.

Taylan, Necip, “Ebu'l-Berekât Bağdâdî (1076-1166)", Anahatlarıyla İsâm Felsefesi: Kaynakları, Temsilcileri, Tesirleri, İstanbul: Ensar Neşriyat, 2011, s. 275-278.

et-Tikrîtî, Nâcî, "Ebû'l-Berakât el-Bağdâdî”, el-Felsefetu'lAhlâkıyyetu'l-'Arabiyye 'inde Mufekkirîll-İslâm, Beyrut: Dâru'l-Endelus, 1402/1982, s. 336-342.

Ülken, Hilmi Ziya, "Ebu'l Berekat Bağdadi”, İslâm Felsefesi: Kaynakları ve Tesirleri, [İstanbul]: Türkiye İş Bankası Kültür Yayınları, 1967, s. 220$227 .{ }^{77}$

Wan Abdullah, Wan Suhaimi, "Kreativiti dan imaginasi dalam pengamatan al- Baghdād̄̄”, Kreativiti dan Imaginasi Dalam Psikologi Islami: Pengamatan al-Ghazzālī, al-Baghdādī dan al-Rāzī, ed. Mohd Z. Ismail, Kuala Lumpur: Institut Kefahaman Islam Malaysia (IKIM), 2011, s. 29-53. ${ }^{78}$

\section{Makaleler}

'Abduh, Mușțafâ Muḥammed Yaḥyâ, "Ebû'l-Berakât el-Bağdâdî ve'l'İlmu'l-Illâhî", el-Mecelletu'l-'Ilmiyye li-Kulliyyeti Ușûli'd-Dîn ve'd-Da've bi'zZekâzîk, 21 (2008-09), s. 3777-3822.

el-Âlûsî, Husâm, "Dirâse Naḳdiyye li-Naz̦ariyyeti'l-Feyḍ el-Fârâbiyye ve Nâḳidîhâ min Vicheti Naẓar Mu âsıra”, el-Mevrid, 7:2 (1978), s. 157-176.

77 Yeni Baskı: Ülken, Hilmi Ziya, "Ebu'l-Berekât Bağdâdî (1076-1166)", Eski Yunan'dan Çağdaş Düşünceye Doğru İslâm Felsefesi: Kaynakları ve Etkileri, İstanbul: Ülken Yayınları, 1998, s. 198-204.

78 Yayımlanan bu çalışmaların dışında, Bağdâdî̀nin akıl anlayışını konu edinen kitap bölümü düzeyinde bir çalışmanın yayım sürecinde olduğu ifade edilmektedir: Marcotte, Roxanne D., "L'intellect chez Abū al-Barakāt al-Baghdadī (mort vers 547/1152)", Noétique et théorie de la connaissance dans la philosophie arabomusulmane des IXe-XVIle siècles, ed. Henrik Lagerlund, Paris: Vrin, 2017. https://religions.uqam.ca/component/savrepertoireprofesseurs/cv?mld= e814k4rlOvQ_ (Erişim: 20.04.2017). 
Arnaldez, Roger, "La doctrine de l'âme dans la philosophie d'Abû' IBarakât al-Baghdâdî”, Studia Islamica, 66 (1987), s. 105-112.

el-Bizri, Nader, "In Defence of the Sovereignty of Philosophy: AlBaghdādī's Critique of Ibn al-Haytham's Geometrisation of Place”, Arabic Sciences and Philosophy, 17:1 (2007), s. 57-80.

Cihan, Ahmet Kamil, “Ebu’l-Berekat el-Bağdadi'nin Akıl Görüşü”, Erciyes Üniversitesi Sosyal Bilimler Enstitüsü Dergisi, 28 (2010/1), s. 1-17.

, "Ebu'l-Berekat el-Bağdadi'nin Mantık İlmine Bakışı", İslâmî İlimler Dergisi, 5:2 (2010), s. 35-45.

Dinanî, Gulam Huseyin İbrahim, “Ebu'l-Berekat'ın Akıl Yorumunun Değerlendirilmesi”, Misbah: İslami Düşünce ve Araştırma Dergisi, 4:10 (2015), s. 75-96.

Ebû Rayyân, Muḥammed 'Alî, "Naḳdu Ebî'l-Berakât el-Bağdâdî liFelsefeti İbn Sînâ", Mecelletu Kulliyyeti'l-Âdâb, Câmi'atu'l-İskenderiyye, 12 (1958), s. 19-46.

Freudenthal, Gad \& Zonta, Mauro, "Avicenna among Medieval Jews: The Reception of Avicenna's Philosophical, Scientific and Medical Writings in Jewish Cultures, East And West”, Arabic Sciences and Philosophy, 22 (2012), s. 217-287.

Griffel, Frank, "Between al-Ghazālī and Abū I-Barakāt al-Baghdādī: The Dialectical Turn in the Philosophy of Iraq and Iran During the Sixth/Twelfth Century", In the Age of Averroes: Arabic Philosophy in the Sixth/Twelfth Century, ed. Peter Adamson, London: The Warburg Institute, 2011, s. 45-75.

Hâdimî, 'Aynullâh, "Naḳd u Berresî-i Dîdegâh-i Ebû'l-Berakât Bağdâdî der-bâre-i Çekûnegî-i Peydâyiş-i Keșîr ez Vâhị", Mecelle-i Felsefe ve Kelâmı İslâmî, 43:2 (1389 hş./2011), s. 39-57.

el-Halîfî, Abdu'l-Hakîm, “Naḳdu Ebî'l-Berakât el-Bağdâdî liNaz̧ariyyeti'ș-Șûra ledâ'l-Meşşâ'iyye ve Eșeruhû fî'l-Medreseti'l-Işrâkı̣ıye”, Afkar: Jurnal Akidah \& Pemikiran Islam, 9 (2008), s. 185-222.

Hasnawi, Ahmad, "Boèce, Averroès et Abū al-Barakāt al-Baġdādī, témoins des écrits de Thémistius sur les Topiques d'Aristote", Arabic Sciences and Philosophy, 17:2 (2007), s. 203-265.

İzmirli, İsmail Hakkı, "İslamda Felsefe Cereyanı-6", Darülfünun İlahiyat Fakültesi Mecmuası: Tarihî, lçtimaî, Dinî, Felsefî, 4:17 (1930), s. 9-24. 
Janssens, Jules, "Abū al-Barakāt al-Baghdādī and His Use of Ibn Sīnā's al-Hikma al-'Arūọiyya (or another work closely related to it) in the Logical Part of His Kitāb al-Mu'tabar', Nazariyat: Journal for the History of Islamic Philosophy and Sciences, 3:1 (2016), s. 1-22.79

Marcotte, Roxanne D., "La conversion tardive d'un philosophe: Abū al-Barakāt al-Baghdādī (mort vers 545/1150) sur 'L'intellect et sa quiddité (al'Aql wa māhiyyatu-hu)'", Documenti e Studi sulla Tradizione Filosofica Medievale, 15 (2004), s. 201-226.

Mohamad, Ismail, "Abū al-Barakāt al-Baghdādī: Pengkritik Ibnu Sīnā”, Dakwah, 259:20 (1998), s. 23-27.

Mucâhid, Muntașır Maḥmûd, “Naẓariyyetu'l-Ḥareke fi't-Turâși'lİslâmî”, Mecelletu Âfâki's-Sekâfe ve't-Turâs, 3:11, s. 76-80.

en-Nedvî, Suleymân, "Kitâbu'l-Mu'teber ve Șâhibuh", el-Kitâbu'lMu'teber fî'l-Hikme sonunda, nşr. Zeynu'l-Âbidîn el-Mûsevî v.dğr., Haydarâbâd: İdâretu Cem 'iyyeti Dâ'ireti'l-Ma ârifî'l- 'Usmâniyye, 1357-58/1938-39, c. 3 , s. $230-252$.

Nony, Sylvie, "Les audaces de la physique arabe du XIle siècle: Dans la synthèse d'Abū I-Barakāt al-Baghdādī (m.1152)", MIDEO: Mélanges de I'Institut Dominicain d'Études Orientales du Caire, 29 (2012), s. 27-50.

Özpilavcı, Ferruh, "Akıl Risaleleri Geleneği ve Bu Gelenek İçinde Ebü'l-Berekât el-Bağdâdî'nin Akıl Risalesi”, İslâmî İlimler Dergisi, 5:2 (2010), s. $75-106$.

—_, "Nedensellik Bağlamında Ebü'l-Berekât el-Bağdâdî'nin Meşşâî Gelenek İçindeki Yeri”, Din Bilimleri Akademik Araştırma Dergisi, 10:1 (2010), s. 53-78.

Pinès, Salomon, "Études sur Awḥad al-Zamân Abu'l-Barakât alBaghdâdî”, Revue des Études Juives, 103 (1938), s. 3-64.

, "Études sur Awḥad al-Zamân Abu'l-Barakât al-Baghdâdî", Revue des Études Juives, 104 (1938), s. 1-33.80

79 Türkçesi: Janssens, Jules, “Ebü'l-Berekât el-Bağdâdî'nin Kitâbü'l-Mu'teber'inin Mantık Kısmında İbn Sînâ'nın el-Hikmetü'l-Arûziyye'sini (veya onunla yakından ilişkili diğer bir eseri) Kullanımı", çev. Muhammet F. Kılıç, Nazariyat: İslâm Felsefe ve Bilim Tarihi Araştırmaları Dergisi, 3:1 (2016), s. 1-22.

80 Pines'in yukarıdaki iki makalesi, birleştirilmiş ve tıpkıbasım olarak yayımlanmıştır: Pines, Shlomo, "Études sur Aḥwad al-Zamân Abu'l-Barakât al-Baghdâdî", The Collected Works of Shlomo Pines, I: Studies in Abu'l-Barakāt al-Baghdādī: Physics 
- - "La conception de la conscience de soi chez Avicenne et chez Abu'l-Barakāt el-Baghdādī", Archives D'Histoire doctrinale et littéraire du Moyen age, 21 (1954), s. 21-98.81

Rûsân, Zâhid Halef, "Ebû'l-Berakât el-Bağdâdî ve İbn Sînâ fî Selâs Mesâ'il Mîtâfizîkıyye", Mu'te li'l-Buhûs ve'd-Dirâsât, 6:3 (2001), s. 139-164.

Shihadeh, Ayman, "Avicenna's Corporeal Form and Proof of Prime Matter in Twelfth-Century Critical Philosophy: Abū I-Barakāt, al-Mas ūdī and al-Rāzī", Oriens, 42 (2014), s. 364-396.

Sözen, Kemal, "Ebu'l-Berekât el-Bağdâdî'nin Zaman Teorisi", Dînî Araştırmalar, 4:10 (2000), s. 161-186.

Stroumsa, Sarah, "On Jewish Intellecual Converts to Islam in the Early Middle Ages", Pe‘amin, 42 (1990), s. 61-75 [ibranca].

eț-Ṭayib, Aḥmed Muhammed, "el-Itticâhu'l-Felsefî 'inde Ebî'l-Berakât el-Bağdâdî”, Afkar: Jurnal Akidah \& Pemikiran Islam, 4 (2003), s. 203-250.

Tunagöz, Tuna, "Ebû'l-Berakât el-Bağdâdî'nin Hudûs Deliline Yönelik Eleştirileri", Çukurova Üniversitesi Illahiyat Fakültesi Dergisi, 12:1 (2012), s. 171-203.

—_, "İslâm Felsefesinin Klâsik Çağında Özgürlükçü Bir Teori: Ebû'l-Berakât el-Bağdâdî'nin Kader Anlayışı", Kutadgubilig: Felsefe-Bilim Araştırmaları Dergisi, 25 (2014), s. 165-193.

—_, "Tanrı'nın Cüz'îlere Dair Bilgisi Tartışmasında Gazzâlî'ye Felsefe Cephesinden Bir Destek", Kelam Araştırmaları Dergisi, 11:1 (2013), s. 393-424.

Üçer, İbrahim Halil, "Ebu'l-Berekat el-Bağdadi Metafiziği", ILEM Yıllık, 3:3 (2008), s. 117-132.

Ülken, Hilmi Ziya, "Ebu-I-Bereqât Bagdadî (1076-1166)", Felsefe Arkivi, 2:3 (1949), s. 119-127.

and Metaphysics, Kudüs: Magnes Press, Hebrew University \& Leiden: Brill, 1979, s. 1-95.

81 Tıpkıbasımlar: (1) Pines, Shlomo, "La Conception de Soi chez Avicenne et chez Abu'l-Barakât al-Baghdâdî", Abū 'Alī ibn Sīnā (d. 428/1037): Texts and Studies, Frankfurt am Main: Institute for the History of Arabic-Islamic Science at the Johann Wolfgang Goethe University, 1999, c. 3, s. 289-366. (2) Pines, Shlomo, "La Conception de Soi chez Avicenne et chez Abu'l-Barakât al-Baghdâdî", The Collected Works of Shlomo Pines, I: Studies in Abu'l-Barakāt al-Baghdādī: Physics and Metaphysics, Kudüs: Magnes Press, Hebrew University \& Leiden: Brill, 1979, s. $181-258$. 
Wan Abdullah, Wan Suhaimi, "Abu Al-Barakat Al-Baghdadi (467547H): Suatu Biografi”, Jurnal Usuluddin, 9 (1999), s. 73-96.

-, "el-Edille 'alâ Vucûdillâhi Te'âlâ 'inde Ebî'l-Berakât elBağdâdî”, Jurnal Usuluddin, 23-24 (2006), s. 255-280.82

, "Ibn Sīnā and Abū al-Barakāt al-Baghdādī on the origination of the soul (Hudūth al-nafs) and the invalidation of its transmigration (Ibtāl altanāsukh)", Islam \& Science, 5 (2007), s. 151-164.83

—, "Konsep IImu Dan Pembelajarannya Mengikut Pandangan Abu Al-Barakat al-Baghdadi (547H)”, Jurnal Usuluddin, 8 (1998), s. 97-106. ${ }^{84}$

_-, "Kajian manuskrip al-Mu'tabar fĩ al-ḥikmah (Kitāb al-Nafs) karangan Abū al-Barakāt al-Baghdādī (547H./1152M.): ke arah suatu kaedah suntingan ilmiah warisan manuskrip Melayu-Islam", Afkar: Jurnal Akidah \& Pemikiran Islam, 6 (2005), s. 273-304.

\section{Ansiklopedi Maddeleri}

Arnaldez, Roger, "Abū I-Barakāt”, Encyclopédie philosophique universelle: Les oeuvres philosophiques, ed. Jean-François Mattéi, Paris: Presses universitaires de France, 1992, c. 3/1, s. 363-367.

Ebû Zeyd, Munâ, "Ebû'l-Berakât el-Bağdâdî”, Mevsû'atu A'lâmi'lFikri'l-İslâmî, Kahire: el-Meclisu'l-A 'lâ li'ş-Şu'ûni'l-İslâmiyye, 1425/2004, s. 137-140.

82 Yayımlanan bu çalışmaların dışında, Bağdâdî ile Şehristânî̀nin varoluş açıklamalarını konu edinen bir makalenin yayım sürecinde olduğu ifade edilmektedir: Lammer, Andreas, "Two Twelfth-Century Hardliners on Creation and Divine Eternity: al-Šahrastānī and Abū I-Barakāt on God's Priority over the World." https://Imu-munich.academia.edu/AndreasLammer (Erişim: 05.03. 2017).

83 Tıpkıbasım: Wan Abdullah, W. S., "Ibn Sīnā and Abū al-Barakāt al-Baghdādī on the origination of the soul (Hudūth al-nafs) and the invalidation of its transmigration (Ibțāl al-tanāsukh)", Islam and Science: Historic and Contemporary Perspectives II: Contemporary Issues in Islam and Science, ed. Muzaffar lqbal, New York: Routledge, 2012, s. 111-124.

84 Genişletilmiş İngilizce baskı: Wan Abdullah, W. S., "Abū al-Barakāt al-Baghdādī's Concept of Knowledge and its Acquisition", 2nd Workshop on Kalam Epistemology Paper Presentations,

http://www.issimalaysia.org.my/home/wp-content/uploads/2016/03/Abu-al-

Barakats-Concept-of-Knowledge-and-its-Acquisition.pdf. (Erişim: 05.03.2017).

ÇÜiFD, 2017, cilt: 17, sayı: 1, ss. 187-225 
Alfâ, Rûnî îlî, "İbn Melkâ, Hibetullâh b. 'Alî el-Beledî”, Mevsû'atu A 'lâmi'l-Felsefe: el- 'Arab ve'l-Ecânib, Beyrut: Dâru'l-Kutubi'l-'Illmiyye, 1412/1992, c. 1, s. 38-39.

Bedevî, Abdu'r-Rahmân, "Ebû'l-Berakât”, Mevsû 'atu'l-Felsefe, Beyrut: el-Mu'essesetu'l- 'Arabiyye li'd-Dirâsât ve'n-Neşr, 1984, c. 1, s. 78-79.

Çağrıcı, Mustafa, "Ebü'l-Berekât el-Bağdâdî”, Türkiye Diyanet Vakfı Issâm Ansiklopedisi, İstanbul: TDV, 1994, c. 10, s. 300-309.

Ebû Rayyân, Muḥammed 'Alî, "Ebû'l-Berakât el-Bağdâdî", Mevsû'atu'l-Haḍârati'l-İslâmiyye, Amman: Menşûrâtu'l-Mecma'i'l-Melikî liBuhûsisi'l-Haḍârati'l-İslâmiyye, 1993, c. 1, 42-45.

Hayyir, Muḥsin, "İbn Melkâ (Hibetullâh b. 'Alî)”, el-Mevsû'atu'l'Arabiyye, Şam: Hey' etu'l-Mevsû 'ati'l- 'Arabiyye, 2007, c. 19, s. 440-441.

Langermann, Yitzhak Tzvi, "Abū 'I-Barakāt", Encyclopaedia of the History of Science, Technology, and Medicine in Non-Western Cultures, ed. Helaine Selin, [New York]: Springer Science+Business Media, B. V., 1997, s. 67.85

—, "Al-Baghdadi, Abu 'I-Barakat (fl. c.1200-50)", Routledge Encyclopedia of Philosophy, ed. Edward Craig, London: Routledge, 1998, c. 1, s. 636-638.

-, "Al-Baghdadi, Abu 'I-Barakat (fl. c.1200-50)", Concise Routledge Encyclopedia of Philosophy, ed. Edward Craig, London \& New York: Routledge, 2000, s. 74.

Madelung, Wilferd, "Abu'l-Barakāt al-Baḡdādī, Awḥad-al-Zamān Hebatallāh b. 'Alī b. Malkā Baladī”, Encyclopaedia Iranica, ed. Ehsan Yarshater, London: Routledge and Kegan Paul, 1983, c. 1, s. 266-268.

Marcotte, Roxanne D., "Abū I-Barakāt al-Baghdādī", Encyclopedia of Medieval Philosophy: Philosophy Between 500 and 1500, ed. Henrik Lagerlund, New York: Springer, 2011, s. 10-12.

Muvaḥhịid, Șamed, "Ebû'l-Berakât, Hibetullâh b. 'Alî (Elî) b. Melkâ (Melkân) Bağdâdî”, Dâ'iretu'l-Ma 'ârif-i Bozorg-i İslâmî, ed. Muḥammed Kâẓım

85 Diğer baskılar: (1) Langermann, Y. Tzvi, "Abū 'I-Barakāt", Encyclopaedia of the History of Science, Technology, and Medicine in Non-Western Cultures, ed. Helaine Selin, Berlin \& New York: Springer, 2008, s. 8-9. (2) Langermann, Y. Tzvi, "Abū 'I-Barakāt", Encyclopaedia of the History of Science, Technology, and Medicine in Non-Western Cultures, ed. Helaine Selin, Berlin \& New York: Springer, 2016, s. 8-9. 
Mûsevî Bûcnûrdî, Tahran, Merkez-i Dâ'iretu'l-Ma'ârif-i Bozorg-i İslâmî, 1372 hş./1993-94, c. 5, s. 202-209. ${ }^{86}$

Pines, Shlomo, "Abu 'I-Barakāt Hibat Allāh b. Malkā al-Baghdadi alBaladī", The Encyclopaedia of Islam, New Edition, Leiden: E. J. Brill, 1960, c. 1, s. 111-113.87

Schloessinger, Max, "Hibat Allah Abu al-Barakat b. 'Ali b. Malka (Malkan) al-Baladi”, The Jewish Encyclopedia, New York: Funk and Wagnalls, 1904 , c. 6 , s. 384 .

Stillman, Norman Arthur \& Pines, Shlomo, "Abū'l-Barakāt alBaghdādī", Encyclopedia of Jews in the Islamic World, ed. Norman A. Stillman, Leiden: Brill, 2010, c. 1, s. 31-34.

eş-Şebîbî, Muḥammed Rıżâ, "el-Felsefetu'l-İslâmiyye fî Edvârihâ'lMuhtelife”, Dâ'iretu'l-Ma ârifíll-Islâmiyyeti'ş-Şî'iyye, ed. Hasen el-Emîn, Beyrut: Daru't-Te âruf li'l-Mațbû ât, 1422/2002, c. 17, s. 179-193.

Zobel, Moshe Nahum, "Hibat Allah, Abu Al-Barakāt (Nathanel) Ben Ali (Eli) Al-Baghdādī”, Encyclopaedia Judaica, Berlin: Verlag Eschkol A.-G., 1931 , c. 8.88

\section{Bilimsel Toplantılarda Sunulan Çalışmalar}

Muehlethaler, Lukas, "Abū I-Barakāt al-Baghdādī's Kitāb al-Mu'tabar and the Avicennan Tradition", AJS 42nd Annual Conference, Boston, 19-21 Aralık 2010.

"Bare self-awareness as cognitive basis in the epistemology of Abū I-Barakāt al-Baghdādī”, The 3rd SSALT Workshop, Between Selfhood

86 İngilizce Çeviri: Mowahhed, Samad, "Abū al-Barakāt, Hibat Allāh b. 'Alī b. Malkā (Eli ben Malkān) al-Baghdād̄̄”, çev. Maryam Rezaee \& Jawad Qasemi, Encyclopaedia Islamica, ed. Wilferd Madelung \& Farhad Daftary, Leiden: E. J. Brill, 2008, c. 1, s. 632-644.

87 Fransızca Çeviri: Pines, Shlomo, "Abu'l-Barakāt Hibat Allāh b. Malkā al-Baghdādī al-Baladî", Encyclopédie de l'Islam, Nouvelle édition, Leiden: Brill \& Paris: G.-P. Maisonneuve \& Larose, 1980 , c. 1, s. 114-116.

88 Diğer baskılar: (1) [Roth, Cecil (ed.)], "Hibat Allah, Abu Al-Barakāt (Nathanel) Ben Ali (Eli) Al-Baghdādī”, Encyclopaedia Judaica, ed. Cecil Roth, Kudüs: Keter Publishing House, [1971], c. 8, s. 461-462. (2) Encyclopaedia Judaica (Germany), "Hibat Allah, Abu Al-Barakāt (Nathanel) Ben Ali (Eli) Al-Baghdādī", Encyclopaedia Judaica, Second Edition, ed. Fred Skolnik v.dğr., New York \& London: Thomson Gale, 2007, c. 9, s. 92-93. 
and Self-awareness: Varieties of Subjectivity in the Arabic and Latin Traditions, Berlin, The Finnish Institute, 12 Nisan 2012.

, "The Reception of Abū al-Barakāt's Philosophical Work: A Reappraisal", EAJS Conference Judaism in the Mediterranean Context, Ravenna-İtalya, 25-29 Temmuz 2010.

—_, "'Umar ibn Sahlān al-Sāwī's Nahj al-taqdīs and the Early Reception of Abū al-Barakāt al-Baghdādī's Philosophical Work", 8th International Conference of the SIHSPAI: Philosophy and Science in Classical Islamic Civilisation, Londra, 3-5 Aralık 2010.

Okan, Kutlu, "Husulî ile Huzurî Bilgi Arasında: Ebu'l-Berekât elBağdadî'nin Epistemolojisi ve İbn Sina Eleştirileri”, IV. Türkiye Lisansüstü Çalışmalar Kongresi Bildiriler Kitabı V: Felsefe-Eğitim-Illetişim, İstanbul: Matsis Matbaa, 2015, s. 91-102.

Barakat's Understanding of the Aql al-Faal", Representation and Reality, Workshop 15: De Anima in the Arabic Tradition, Göteborg-İsveç, 28-29 Nisan 2017.

Tunagöz, Tuna, “Ebü'l-Berekât el-Bağdâdî’nin Risâle fî mâhiyyeti’melâl Adlı Eseri Üzerine”, Asos Congress Bildiri Kitabı, Elazığ: Asos Yayınları, 2016, s. 2666-2678.

—_, "Ebü'l-Berekât el-Bağdâdî'nin Risâle fî sebebi zuhûri'l-kevâkib leylen ve hafâiha nehâran İsimli Risalesi Üzerine", 14. Uluslararası Türk Dünyası Sosyal Bilimler Kongresi: Bildiriler Kitabı, İstanbul: Türk Dünyası Araştırmaları Vakfı, 2016, s. 150-157.

—_, "Ebü'l-Berekât el-Bağdâdî Felsefesinde İnsan Özgürlüğü”, 14. Uluslararası Türk Dünyası Sosyal Bilimler Kongresi: Bildiriler Kitabı, İstanbul: Türk Dünyası Araştırmaları Vakfı, 2016, s. 158-168.

Ülken, Hilmi Ziya, "Un philosophe de l'Islam: Ebu-I-Berekat Bagdadi”, Proceedings of the Tenth International Congress of Philosophy, ed. E. W. Beth \& H. J. Pos, Amsterdam: Library of the 10th International Congress of Philosophy, 1949, s. 270-273.89

89 Temmuz 2017'de Berlin'de gerçekleşecek bir uluslararası konferansta, Hârizmşahlar devleti inşâ kâtibi Vațvâț’ın kaleme aldığı iki davet mektubunu esas alan "İslâm Tıp Tarihi Araştırmalarına Bir Katkı: Hârizmşahlar Devleti Yazışmalarında Tabip Ebü'l-Berekât el-Bağdâdî ve Hibetullah İbnü't-Tilmîz" isimli bir bildiri sunacağım. 


\section{Sonuç ve Değerlendirme}

Bağdâdî'nin temel eseri el-Kitâbu'l-Mu'teber'in, tam ve eksik, on yedi nüshası mevcuttur. Bu nüshaların sekizi Türkiye, yedisi İran, biri Irak, biri de Suriye kütüphanelerinde yer almaktadır. Yalnızca Irak'taki nüsha (Haydariyye 576) onun sağlığında çoğaltılmıştır ve eserin neşirlerinin hiçbirisinde kullanılmamıştır. Vefatının akabinde çoğaltılan nüshalar içerisinde en önemlileri ise, İstanbul'dan Haydarabad'a nakledilen ve şu an mevcudiyeti hakkında kesin bir bilgi bulunmayan Âsafiyye nüshası ile Lâleli 2553, Es'ad Efendi 1931, Fâzıl Ahmed Paşa 919, Şûrâ-yı İslâmî 10612, Fâtih 3224, 3225, 3226, Rażavî 5666 ve Yusuf Ağa 4690/6'dır. Son altı nüsha, şimdiye dek yapılan üç ayrı neşrin hiçbirisinde kullanılmamıştır.

el-Kitâbu'l-Mu 'teber'in neşirleri içerisinde en sağlıklısı, Zeynu'l- 'Âbidîn el-Mûsevî ve arkadaşları tarafından Haydarabad'da 1938-39 yılları arasında tamamlanmış olanıdır. Devrinin koşulları bakımından iyi olduğu söylenebilecek bu neşrin en büyük eksikliği, kullandığı nüsha sayısının bugün için yetersiz kalması, günümüz tahkik standartlarını karşılamaması ve imla-dizgi sorunlarıdır. Bu metni esas alan Yûsuf Maḥmûd ve Muḥammed 'Ușmân tarafından yapılan muahhar neşirler eseri yanlış isimlendirdiği gibi, sadece daha iyi bir dizgi ve imla sunmuş durumdadır. Dolayısıyla, Bağdâdî'nin bu asıl eserinin, mevcut en iyi yazmalara dayanan ve daha gelişkin bir tekniğe sahip bir neşrinin hazırlanması önem arzetmektedir. Ayrıca, zor bir üsluba sahip bu eserin İngilizceye ve/veya Türkçeye çevrilmesi, Bağdâdî'nin felsefî sisteminin anlaşılmasına önemli katkılar sağlayacaktır. Birkaç çalışma içerisindeki kısmî çeviriler, araştırmacılara bu hususta yardımcı olacak niteliktedir.

Tek nüshası bulunan Risâle fî'l- 'Aḳl, on altı nüshası bulunan Risâle fî Sebebi Zuhûri'l-Kevâkib ve dört nüshası bulunan Risâle fî Mâhiyyeti'l-Melâl isimli eserler incelenmiş, tahkik edilmiş ve Türkçeye çevrilmiş durumdadır. İki eksik nüshası bulunan Kitâbu'n-Nefs ile eksik ve tam birer nüshası bulunan Kôhelet Şerhi'nin inceleme, tahkik ve İngilizce çeviri olarak yayıma hazırlandığı ifade edilmektedir. Bu durumda henüz çalışılmamış eserler olarak filozofun günümüze ulaşan iki tıp eseri Berşe 'aşâ ile Emînu'l-Ervâh kalmaktadır. Berşe 'aşâ'nın sekiz nüshasının üçü Türkiye'de, üçü İran'da, biri Mısır'da, biri de Japonya'dadır. Emînu'l-Ervâh'ın eldeki tek nüshası ise Türkiye'dedir. Her iki risalenin inceleme, tahkik ve çeviri olarak ilim dünyasına kazandırılması Bağdâdî'nin düşünce dünyasının aydınlatılması bağlamında önemli bir kazanıma karşılık gelecektir. Eğer yazmaları tespit edilebilirse İhtișâru't-Teşrîh ve elAḳâabâzîn de bu listeye eklenmelidir. 
Bağdâdî'nin hayatı ve eserleri, on yedisi klasik, yirmi dokuzu muasır kırk üç eser içerisinde konu edilmektedir. Klasik dönem eserleri, Bağdâdî'nin yaşamöyküsünü ve ilmî kişiliğini aktarma bakımından önemli boşluklar barındırmaktadır. Bunlar içerisinde Beyhaḳî ile İbn Ebî Ușaybi'a'nın eserlerinin daha zengin bir içeriğe sahip olduğu söylenebilir. Muasır eserler ise, büyük çoğunluğu itibariyle, birbirini tekrar eden bilgiler sunmaktadır.

Bağdâdî hakkında bilgi verilen ilk akademik çalışma Ferdinand Wüstenfeld'e aittir. Müslüman tıp ve tabiat âlimlerini tanıtan 1840 tarihli bu çalışmayı, çoğunluğu yine biyo-bibliyografik nitelikteki, Leclerc, Brockelmann, Suter, Steinschneider ve Schloessinger'in çalışmaları takip etmiştir. 1904 yılında yayımlanan sonuncusunun ardından Wiedemann'ın 1909 tarihli eser incelemesi ve tasvirî tercümesi gelmiştir. Tüm bunlar bahsedilen yarım yüzyılı aşan sürece Alman akademisinin damgasını vurduğunu ifade etmektedir. Fakat bu etkin rol sonraki dönemde ortadan kalkmıştır.

Eski tarihli çalışmalar içerisinde en kapsamlı ve bu nedenle önemlisi, Yaltkaya'nın 1930-31 tarihleri arasında artarda yayımladığı altı makaledir. Yaltkaya, bu çalışmalarda, Bağdâdî'nin hayatına ve eserlerine yönelik önceki eserlerden çok daha ayrıntılı bilgiler vermiş; en önemlisi el-Kitâbu’Mu'teber'in metafizik bölümünün önemli bir kısmını Türkçeye çevirmiştir. Bu makaleler bir yıl sonra müstakil bir kitap içerisinde toplanmıştır. Diğer önemli çalışma, el-Kitâbu'l-Mu'teber'in neşrinin ardına en-Nedvî'nin eklediği makaledir. Shlomo Pines, 1938 yılında yayımlanan iki önemli makalesi ile filozof hakkında yapılan çalışmalara iştirak etmeye başlamıştır. Ülken 1949 tarihli bildiri ve makalesi ile bu sürece katılmış; sonraki döneme yön veren isim, sonuncusu 1979'da yayımlanan farklı nicelikteki müteakip sekiz müstakil çalışmasıyla Pines olmuştur.

Bağdâdî felsefesi üzerine, on beşi yüksek lisans, on yedisi doktora olmak üzere otuz iki tez hazırlanmıştır. Bunların ilki, Mehmet Dağ'ın 1970 tarihli doktora tezidir. Tezlerin on üçü Arapça, sekizi İngilizce, yedisi Türkçe, ikisi Fransızca, biri Felemenkçe, biri de Malayca'dır. Bu çalışmaların dokuzu Mısır, yedisi Türkiye, dördü Malezya, dördü Irak, ikisi Fransa, ikisi İngiltere, ikisi İsrail, ikisi Hollanda, biri Suudi Arabistan üniversitelerinde gerçekleştirilmiştir. Tezler, Bağdâdî'nin fizik ve metafizik teorileri ile felsefesindeki eleştirelliğe odaklanmış durumdadır. Üç tezde ise filozofun mantık anlayışı incelenmiştir. Tezlerin önemli bir kısmının Türk akademisyenlere ait ve Türkçe olması -ki Türkçe iki tezin devam ettiği de belirtilmektedir- dikkat çekici bir husustur. Tezlerin dışında, kitap, kitap bölümü, makale, ansiklopedi maddesi, bildiri gibi çalışmalarda da bu durum devam etmektedir. Bağdâdî'nin eserlerinin yazma- 
larının önemli bir kısmının Türkiye'deki kütüphanelerde bulunması, Şerafeddin Yaltkaya'nın öncü çalışmaları ve Hilmi Ziya Ülken'in 1949'a uzanan araştırmaları bu durumun nedeni olarak gösterilebilir.

Filozof hakkında yayımlanan kitapların sayıca az olduğu görülmektedir. Çoğu, araştırmacıların tezlerine dayanan bu eserler on beş adettir. Kitapların yedisi Arapça, üçü İngilizce, ikisi Türkçe, ikisi Fransızca, biri de Farsçadır. Pines imzalı ilk kitabın yayım tarihi 1955'tir. En kapsamlı eser de ona ait 1979 tarihli çalışmadır. 'Îdî'nin eseri, Bağdâdî üzerine tespit edebildiğim üç Farsça çalışmadan birisi durumundadır. Çalışmaların çoğunun 2000'lerden sonra ve dördünün 2016 itibariyle yazılmış olması, kitap çalışmalarının artacağı yönünde bir izlenime kapı aralamaktadır. Kitapların tezlerle aynı konulara odaklandığı görülmektedir. Fakat burada mantık bahsi yer almamaktadır.

Bağdâdî felsefesi ile ilgilenen kırk sekiz kitap bölümü bulunmaktadır. Bu çalışmaların on sekizi İngilizce, onu Arapça, yedisi Fransızca, altısı Türkçe, üçü Almanca, ikisi İbranca, biri Malayca ve biri de Lehçedir. Pines, Ebû Rayyân ve Ülken tarafından kaleme alınmış bölümler, çalışmalar içerisinde ön plana çıkmaktadır. Dikkat çeken hususlardan birisi, İslâm felsefesi tarihine yönelik eski ya da yeni tarihli çalışmaların büyük çoğunluğunda Bağdâdî ile ilgili bir bölüm bulunmamasıdır. Corbin, Ebû Rayyân, Ülken, Taylan ve Adamson'un çalışmaları az sayıdaki istisnaya karşılık gelmektedir.

Makaleler, tüm çalışmalar içerisinde en büyük yekûnu tutmaktadır. Türkçe yayın sayısının diğer dillerin çok önünde oluşu dikkat çekicidir. Tespit edebildiğim elli üç makalenin, yirmi biri Türkçe, dokuzu Arapça, sekizi İngilizce, yedisi Fransızca, dördü Malayca, ikisi İbranca, biri Almanca, biri de Farsçadır. Bu çalışmalar Bağdâdî'nin eserlerin neşirleri, çevirileri; onun mantık, fizik, metafizik sahasındaki görüşleri ve Meşşâî felsefeye alternatif yorumlarını konu edinmekte ve içeriğin çeşitliliği bakımından kitap bölümleri ile birlikte en önemli yayın grubunu oluşturmaktadır.

Ansiklopedilerde Bağdâdî’yi konu edinen madde sayısı yirmidir. Bunların onu İngilizce, altısı Arapça, ikisi Fransızca, biri Türkçe, biri Farsça, biri de Fransızcadır. Maddelerin önemli bir kısmı hemen hemen aynı bilgileri tekrarlamaktadır. Çağrıcı ve Muvaḥhid tarafından kaleme alınan maddeler diğerleri içerisinde ön plana çıkmaktadır.

Bilimsel toplantılarda sunulan çalışmaların, 1949 yılında başlamış olsalar da, oldukça yetersiz olduğu görülmektedir. Toplam on etkinliğin sadece beşi basılmış durumdadır. 
Tüm bu çalışmalar içerisinde en büyük eksiklik, Ebû'l-Berakât elBağdâdî felsefesini bütüncül olarak değerlendiren bir eserin ortaya çıkmamış olmasıdır. el-Kitâbu'l-Mu 'teber'in neşir ve tercümesinin ve Bağdâdî'nin mantık anlayışına daha yoğun ilginin sözü edilen çalışma için hazırlık basamağı olacağı aşikârdır. Yine, mevcut iki tıp eserinin neşri, düşünürün meşhur tabipliğini ve İslâm tıp tarihindeki yerini ortaya koyacak çalışmalara kapı aralayacaktır. Dinî ve felsefî literatürü vukufla inceleyen ve bu müktesabatı uzun bir tefekkür sürecinin ardından özgün bir düşünce sistemine dönüştüren filozofun felsefî kaynakları ve düşünce tarihine etkisi ilgilenilmesi gereken diğer araştırma alanlarıdır. Felsefî kelâmın zirve isimlerinden ve İslâm düşüncesinin dönüştürücülerinden Fahru'd-Dîn er-Râzî üzerindeki etkisi henüz incelenmemiştir. Filozofun İşrâkî felsefe ile İbn Teymiyye düşüncesi üzerindeki; ayrıca giriş bölümünde zikredilen gayr-ı müslim düşünürlere etkisi de akademik ilgiyi beklemektedir. 


\section{Works on Abū'l-Barakāt al-Bağdādī: \\ A Bibliographical Essay}

Citation/@- Tunagöz, T. (2017). Works on Abū'l-Barakāt alBağdādī: A Bibliographical Essay, Çukurova University Journal of Faculty of Divinity, 17 (1), 187-225.

Abstract- In this paper I present a bibliography of Abū'lBarakāt al-Baǵdādī (d.547/1152), who is one of the leading figures in the history of Islamic Philosophy. Initially some brief information about his scientific personality is given and then the method of our examination is explained. The manuscripts of al-Bagidādi's works, publishing and translations of them, and the published books, sections, papers and encyclopedia papers are listed in the study. Also I noticed the classical and modern books giving information about the life and works of the philosopher. One of the key findings of our examination is that the number of the studies about alBağdādī has rapidly increased in recent years and focused on the criticism in his philosophy. Neither some works of the philosopher have been published nor the huge part of the issues in his thought have been examined yet. On the other hand, al-Baǵdādi's intellectual sources and his effects are waiting for the researchers' attention.

Keywords- Abū'l-Barakāt al-Bağdādī, bibliographical essay, history of Islamic philosophy, history of Islamic science, history of Islamic medicine 